Global COE Hi-Stat Discussion Paper Series 058

$$
\begin{aligned}
& \text { Research Unit for Statistical } \\
& \text { and Empirical Analysis in Social Sciences (Hi-Stat) }
\end{aligned}
$$

Testing the general validity of the Heckscher-Ohlin Theorem: the natural experiment of Japan

\author{
Daniel M. Bernhofen \\ John C. Brown
}

April 2009 


\title{
Testing the general validity of the Heckscher-Ohlin Theorem: the natural experiment of Japan ${ }^{1}$
}

\author{
Daniel M. Bernhofen \\ University of Nottingham and GEP \\ and \\ John C. Brown \\ Clark University and GEP
}

March 31, 2009. ${ }^{2}$

\begin{abstract}
We exploit Japan's $19^{\text {th }}$ century opening up to trade to test a general formulation of the Heckscher-Ohlin theorem. This formulation is based on Ohlin's measure of factor scarcity where autarky factor prices impose a refutable prediction on the economy's factor content of trade. Our test combines factor price data in Japan's autarky period with commodity trade data and a technology matrix in Japan's early free trade period. Our technology matrix is derived from a major Japanese survey of agricultural techniques during the early Meiji period, accounts by European visitors and numerous studies by Japanese and western scholars that draw on village records, business accounts and other historical sources. Evaluating Japan's factor content of trade during 1868-1875 at the corresponding autarky factor prices, we fail to reject the HeckscherOhlin prediction in each sample year.
\end{abstract}

\footnotetext{
${ }^{1}$ Addresses for Correspondence: Daniel Bernhofen, School of Economics and GEP, University of Nottingham, University Park, Nottingham, NG7 2 RD, UK. Tel: 44115846 7055, Fax: 441159514159 , email: daniel.bernhofen@,nottingham.ac.uk or John Brown, Department of Economics, Clark University and GEP, 950 Main Street, Worcester, MA 01610, USA; Tel: 011508793 7390, Fax: 508793 8849, jbrown@clarku.edu.

${ }^{2}$ We acknowledge the generous support of National Science Foundation Grant SES-0452991 and the Leverhulme trust. Leonid Krasnozhon and Shoji Masahiro provided valuable research assistance.
} 


\section{Introduction}

This paper provides the first test of the general validity of the Heckcher-Ohlin theorem as formulated by Alan Deardorff (1982). An attractive feature of Deardorff's formulation is that it provides a refutable hypothesis on an economy's factor content of trade which holds under very general circumstances. The challenge of testing this Heckscher-Ohlin prediction is that it requires compatible data of a market economy under both autarky and free trade. This paper exploits a unique data set on Japan's $19^{\text {th }}$ economy shortly before and after its opening up to test this general Heckscher-Ohlin prediction.

The Heckscher-Ohlin theory predicts the pattern of trade by differences in countries' relative factor scarcity. Since relative factor scarcity can be measured in two different ways, there are two different theoretical traditions of formulating the HeckscherOhlin theorem, associated with the names of Wassily Leontief and Bertil Ohlin. In the Leontief or quantity formulations, factor scarcity is measured by data on countries' factor endowments. In the Ohlin or price formulations, factor scarcity is measured by autarky factor prices. Given the difficulty of observing autarky, the empirical Heckscher-Ohlin literature has focused exclusively on the quantity formulations of Heckscher-Ohlin. In particular, the Heckscher-Ohlin theorem as formulated by Jaroslav Vanek (1968) has dominated the empirical Heckscher-Ohlin literature for the last three decades. A shortcoming of the Heckscher-Ohlin-Vanek formulation is that it is based on fairly restrictive assumptions such as factor price equalization and identical homothetic preferences. ${ }^{3}$

To our knowledge, we are the first to test the Heckscher-Ohlin theorem in its Ohlin or price formulation. This formulation goes back to Deardorff (1982) who has shown that a country's autarky factor price vector imposes a restriction on the country's factor content of trade. Specifically, it predicts that the factor content of net imports valued at autarky factor prices is positive. This prediction can be interpreted as saying that autarky factor prices are positively correlated with the quantity of factor services

\footnotetext{
${ }^{3}$ The most prominent empirical papers on Heckscher-Ohlin-Vanek are Bowen et al (1987), Trefler (1993, 1995) and Davis and Weinstein (2001). The latter papers made important contributions in relaxing some of the restrictive assumptions of the Heckscher-Ohlin-Vanek formulation. However, as a trade-off, the literature has moved away from testing to the accounting of trade in factor services.
} 
embodied in the country's net imports. Hence, a country will, on average, import factor services that are scarce and export factor services that are abundant.

Although Deardorff's formulation does not require factor price equalization or specific preference symmetries, he derives his results using different ways of measuring a country's factor content of trade under the assumption of identical technologies. ${ }^{4}$ In an important follow-up work, Neary and Schweinberger (1986) have shown that Deardorff's price formulation of the Heckscher-Ohlin Theorem can be derived without assuming identical technologies. Building on Meade (1952) and Woodland's (1980) concepts of direct and indirect trade utility functions, Neary and Schweinberger (1986) introduce the concept of factor content functions and their duals. Applying these tools to the Heckscher-Ohlin Theorem, they show that the gains from trade is a sufficient condition for obtaining Deardorff's prediction as long as the factor content of trade is measured using the home economy's technology matrix.

In Bernhofen and Brown $(2004,2005)$ we identified Japan's rapid integration into the international economy in the mid-nineteenth century after over two centuries of nearly complete economic isolation as a natural experiment compatible with the autarkyfree trade paradigm of neoclassical trade theory. By combining data on the commodity pattern of trade with goods price data under autarky, we were able to test the law of comparative advantage and offer an upper-bound estimate of the comparative advantage gains from trade. The next question in the case of Japan — and in trade theory - is to investigate the sources of comparative advantage.

Our prior evidence of gains from trade arising from Japan's opening up implies the validity of the sufficient condition for the prediction which means that there is something at stake in testing Heckscher-Ohlin since a rejection could not be accounted for by unmet assumptions. In a related manner, although we know that the law of comparative holds for Japan, this does not let us foresee the outcome of the test prior to execution. Our previous finding that the economy's commodity net import vector valued at commodity goods prices is positive still leaves it open whether the sign of the factor content of net imports valued at autarky factor prices will be ;positive.

\footnotetext{
${ }^{4}$ Although Deardorff's key theorem focuses on a single economy, he generates predictions on the pattern of the factor content of trade based on the autarky prices of all trading partners.
} 
Our test combines factor price data in the autarky period with commodity trade data and a technology matrix developed for tradeable goods during the early free trade period. The data on wages, rental rates of capital and land rents stem from a range of historical studies of the late Tokugawa and early Meiji periods. The technology matrix is derived from a major Japanese survey of agricultural techniques during the early Meiji period, accounts by European visitors and numerous studies by Japanese and western scholars that draw on village records, business accounts and other historical sources. Applying the data to the theory, we cannot reject the Heckscher-Ohlin prediction in each single sample year.

In section 2 we start out with an intuitive discussion of the quantity and the price measures of relative factor scarcity in the two-factor case. Using a simple graphical framework, we illustrate the inter-relationship between the gains from trade in factor service space and the price formulation of the Heckscher-Ohlin Theorem. Building on Neary and Schweinberger (1986), section 3 uses the concepts of factor trade utility and factor trade expenditure functions to derive the general Heckscher-Ohlin theorem.

Section 4 discusses the empirical domain and the data sources for the construction of the technology matrix and the autarky factor prices. Section 5 describes the technology matrix, calculates the observed factor content of trade and provides the first preliminary test results. Section 6 concludes.

\section{Gains from trade and the price formulation of Heckscher-Ohlin}

Consider a small open economy, called home, which has the opportunity to trade with the rest of the world (ROW). We initially restrict ourselves to the case where the economy produces $n$ goods using only two factors of production, factor 1 and factor 2 , given by $\mathbf{V}=\left(\mathrm{V}_{1}, \mathrm{~V}_{2}\right)$ in Figure 1 .

Under autarky, the allocation of factors to the production of the $n$ goods is determined by home's factor supplies, the country's technology and consumer preferences. The autarky equilibrium is characterized by equilibrium goods and factor prices. Since our focus is on factor service trade, we can restrict our attention to the economy's equilibrium autarky factor price vector $\mathbf{w}^{\mathbf{a}}=\left(\mathrm{w}_{1}^{\mathrm{a}}, \mathrm{w}^{\mathrm{a}}{ }_{2}\right)$. The vectors $\mathbf{V}$ and $\mathbf{w}^{\mathbf{a}}$ 
determine home's gross domestic product (GDP) under autarky: GDP ${ }^{\mathrm{a}}=\mathrm{w}_{1}^{\mathrm{a}} \mathrm{V}_{1}+\mathrm{w}_{2}^{\mathrm{a}} \mathrm{V}_{2}$. Alternatively, $\mathbf{V}$ and $\mathbf{w}^{\mathbf{a}}$ can be thought of defining an autarky GDP factor line, as depicted in Figure 1. The factor line goes through the endowment point $\mathbf{V}$ and has a slope of $-\mathrm{w}^{\mathrm{a}}{ }_{1} / \mathrm{w}^{\mathrm{a}}{ }_{2}$. The line's intercept with the horizontal axis measures autarky GDP in units of factor 1 and its intercept with the vertical axis measures autarky GDP in units of factor 2.

Figure 1 is helpful in illustrating and contrasting the two ways of measuring relative factor scarcity: Leontief's quantity measure and Ohlin's price measure. Leontief's quantity measure of the relative scarcity of factor 1 is given by the economy's relative endowment ratio $\mathrm{V}_{1} / \mathrm{V}_{2}$. In contrast, Ohlin's price measure of the relative scarcity of factor 1 is given by the equilibrium autarky factor price ratio $\mathrm{w}_{1}^{\mathrm{a}} / \mathrm{w}^{\mathrm{a}}{ }_{2}$. The key point is that since Ohlin's price measure of relative factor scarcity embodies more information about the economy's underlying fundamentals than the quantity measure. ${ }^{5}$ Assume that the economy experiences a sudden shift in demand towards the goods that make relatively intensive use of factor 1, ceteris paribus. Since the factor endowments have not changed, this shift in demand does not affect the quantity measure of factor scarcity $V_{1} / V_{2}$. However, such a shift in the relative demand of factor 1 will increase the relative scarcity of this factor. This increase in relative factor scarcity will be captured by an increase in the relative autarky price $\mathrm{w}^{\mathrm{a}}{ }_{1} / \mathrm{w}^{\mathrm{a}}$. As a result, the new autarky equilibrium will be characterized by a steeper autarky GDP factor line. Now since the new autarky GDP factor line will still go through V, its horizontal intercept shifts to the left and its vertical intercept will shift up. This implies a decrease in GDP when measured in units of factor 1 and an increase in GDP when measured in units of factor 2, or an increase in the relative scarcity of factor 1.

The above discussion illustrates that Ohlin's price measure of factor scarcity embodies more information about an economy's relative factor scarcity than the quantity measure. As a result, a Heckscher-Ohlin formulation which is based on Ohlin's price measure requires fewer assumptions on the economy. In fact, we can show that the gains from trade is a sufficient condition for a Heckscher-Ohlin factor content prediction.

\footnotetext{
${ }^{5}$ The fundamental insight that prices embody all relevant information about relative scarcities was first articulated by Hayek (1945).
} 
The starting point for such a formulation is the specification of a balanced trade condition of the economy with the rest of the world. In particular, the balance of trade in commodity space will imply a balanced trade condition in factor service trade. Denoting the economy's net factor import vector as $\mathbf{M}=\left(\mathrm{M}_{1}, \mathrm{M}_{2}\right)$, (where $\mathrm{M}_{\mathrm{i}}>(<) 0$ if factor $\mathrm{i}$ is imported (exported)), the balance of trade condition requires that $\mathrm{w}_{1}{ }^{\mathrm{f}} \mathrm{M}_{1}+\mathrm{w}_{2}{ }^{\mathrm{f}} \mathrm{M}_{2}=0$, where $\mathrm{w}_{1}{ }^{\mathrm{f}}$ and $\mathrm{w}_{2}{ }^{\mathrm{f}}$ denote the prices under which factor services will be traded internationally. Figure 1 shows that this condition implies that the economy's trade must then occur along its factoral terms of trade line. The factoral terms of trade line is anchored at the economy's endowment point $\mathbf{V}$ and has, in absolute value, a slope of $\mathrm{w}_{1}^{\mathrm{f}} / \mathrm{w}_{2}^{\mathrm{f}}$. The factoral terms of trade line shows that there are only two feasible trading possibilities: export factor 1 and import factor 2 (i.e. $\mathrm{M}_{1}<0$ and $\mathrm{M}_{2}>0$ ) or import factor 1 and export factor 2 (i.e. $\mathrm{M}_{1}>0$ and $\mathrm{M}_{2}<0$ ).

But in which direction will the economy trade? The principle that holds for trade in goods holds also for trade in factor services: the pattern of trade is governed by the gains from trade. International trade in factor services enables the economy to reach an augmented endowment point $\mathbf{V}^{\mathbf{f}}$, defined as $\mathbf{V}^{\mathbf{f}}=\mathbf{V}+\mathbf{M}$. The economy will experience a gain from international trade if the augmented endowment point $\mathbf{V}^{\mathbf{f}}$ lies outside its autarky GDP factor line. Since $\mathrm{w}_{1}^{\mathrm{f}} / \mathrm{w}_{2}^{\mathrm{f}}>\mathrm{w}_{1}^{\mathrm{a}} / \mathrm{w}_{2}^{\mathrm{a}}$, the economy will only experience a gain if it exports factor 1 and imports factor 2. The reason for this is that the relative value of factor 1 is higher in international exchange than it is domestically. In Figure 1, the gains from factor service trade is illustrated by the outward shift of the autarky GDP factor line to $\mathbf{V}^{\mathbf{f}}$.

But how can this trading pattern be explained by a comparison of relative factor scarcities at home and in the ROW? As mentioned before, $\mathrm{w}_{1}{ }^{\mathrm{a}} / \mathrm{w}_{2}{ }^{\mathrm{a}}$ measures the relative scarcity of factor 1 at home. But what is the relative scarcity of factor 1 in the ROW? If the trading equilibrium is characterized by factor price equalization then the economy's factor exchange ratio coincide with the factor prices in the rest of the world: $\mathrm{w}_{1}{ }^{\mathrm{f}}=\mathrm{w}_{1}{ }^{\mathrm{ROW}}$, $\mathrm{w}_{2}{ }^{\mathrm{f}}=\mathrm{w}_{2}{ }^{\mathrm{ROW}}$. If $\mathrm{w}_{1}{ }^{\mathrm{a}} / \mathrm{w}_{2}{ }^{\mathrm{a}}<\mathrm{w}_{1}{ }^{\mathrm{ROW}} / \mathrm{w}_{2}{ }^{\mathrm{ROW}}$, then home is relatively abundant in factor 1 and the above discussion implies that the economy will export its scarce factor and import its abundant factor. However, if the free trade equilibrium is not characterized by factor price equalization, it is easy to show that $\mathrm{w}_{1}{ }^{\mathrm{f}} / \mathrm{w}_{2}{ }^{\mathrm{f}}$ must always lie between $\mathrm{w}_{1}{ }^{\mathrm{a}} / \mathrm{w}_{2}{ }^{\mathrm{a}}$ and 
$\mathrm{w}_{1}{ }^{\mathrm{ROW}} / \mathrm{w}_{2}{ }^{\text {ROW }}$. As a result, $\mathrm{w}_{1}^{\mathrm{a}} / \mathrm{w}^{\mathrm{a}}{ }_{2}<\mathrm{w}_{1}{ }^{\mathrm{ROW}} / \mathrm{w}_{2}{ }^{\mathrm{ROW}}$ implies $\mathrm{w}_{1}{ }^{\mathrm{a} / \mathrm{w}_{2}}{ }^{\mathrm{a}}<\mathrm{w}_{1}{ }^{\mathrm{f}} / \mathrm{w}_{2}{ }^{\mathrm{f}}$ and home will export factor 1 and import factor 2. On the other hand, if home is relatively scarce in factor 1 , i.e. $\mathrm{w}^{\mathrm{a}}{ }_{1} / \mathrm{w}_{2}^{\mathrm{a}}{ }_{2}>\mathrm{w}_{1}{ }^{\mathrm{ROW}} / \mathrm{w}_{2}{ }^{\mathrm{ROW}}$ then $\mathrm{w}_{1}{ }^{\mathrm{a}} / \mathrm{w}_{2}{ }^{\mathrm{a}}>\mathrm{w}_{1}{ }^{\mathrm{f}} / \mathrm{w}_{2}{ }^{\mathrm{f}}$ and the gains from trade imply that home will import its scarce factor 1 and export its abundant factor 2 . This leads us to the following 2-factor price formulation of the Heckscher-Ohlin theorem:

\section{Two-factor formulation of the Heckscher-Ohlin Theorem}

Assume there are gains from trade. If the economy is relatively abundant in a factor relative to the rest of the world, then the commodity pattern of trade will be such that the economy will export the services of its abundant factor and import the services of its scarce factor.

\section{Factor content functions and the general Heckscher-Ohlin Theorem}

Consider a small open economy with $n$ goods and $l$ factors of production. The economy's vector of factor endowments is given $\mathbf{V}=\left(\mathrm{V}_{1}, \ldots, \mathrm{V}_{\mathrm{l}}\right)$. Aggregate production possibilities are characterized by the implicit constraint $F(\mathbf{y}, \mathbf{V}) \leq 0$, where $\mathbf{y}=\left(\mathrm{y}_{1}, \ldots \mathrm{y}_{\mathrm{n}}\right)$, is a vector of net outputs. On the consumption side a single consumer is characterized by a real valued utility function $\mathrm{u}(\mathbf{x})$ which is assumed to be continuous, weakly increasing and quasi-concave with regard to the consumption vector $\mathbf{x}=\left(\mathrm{x}_{1}, \ldots \mathrm{x}_{\mathrm{n}}\right)$. Following Woodland (1980) a direct trade utility function is defined as the maximum utility attainable when domestic production is augmented by a net import vector $\mathbf{T}=\left(\mathrm{t}_{1}, \ldots \mathrm{t}_{\mathrm{n}}\right)$. The direct trade utility function $\mathrm{U}^{\mathrm{d}}$ can be written as:

$$
\mathrm{U}^{\mathrm{d}}(\mathbf{T}, \mathbf{V})=\max \{\mathrm{u}(\mathbf{x}): \mathrm{F}(\mathbf{x}-\mathbf{T}, \mathbf{V}) \leq 0\}
$$

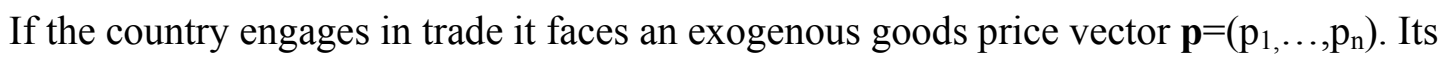
net import vector $\mathbf{T}$ is then constrained to satisfy the balanced trade condition:

$$
\mathbf{p T}=0
$$


The market, or the social planner, can then be thought of choosing a net import vector $\mathbf{T}$ that maximizes the direct trade utility function (1) subject to the balanced trade condition (2). The equilibrium net import vector $\mathbf{T}$ is then a function of $\mathbf{p}$ and $\mathbf{V}$, i.e. $\mathbf{T}=T(\mathbf{p}, \mathbf{V})$.

Alternatively, and following the logic of Neary and Schweinberger (1986), we can look at the trading equilibrium from a factor endowment perspective. For this we consider the concept of a direct factor trade utility function. The direct factor trade utility function is defined as the maximum utility attainable when the domestic endowment vector $\mathbf{V}$ is augmented by a net factor import vector $\mathbf{M}=\left(\mathrm{M}_{1}, \ldots, \mathrm{M}_{1}\right)$. Domestic technology will then be applied to the augmented endowment vector $\mathbf{V}+\mathbf{M}$, which modifies the aggregate production possibilities constraints to $F(\mathbf{y}, \mathbf{V}+\mathbf{M}) \leq 0$. The direct factor trade utility function $\mathrm{U}^{\mathrm{f}}$ is then defined as:

$$
\mathrm{U}^{\mathrm{f}}(\mathbf{M}, \mathbf{V})=\max \{\mathrm{u}(\mathbf{x}): \mathrm{F}(\mathbf{x}, \mathbf{V}+\mathbf{M}) \leq 0\}
$$

We assume that the technology in each sector can be represented by a unit cost function which is increasing, concave and homogeneous of degree one in the economy's factor prices $\mathbf{w}=\left(\mathrm{w}_{1}, \ldots \mathrm{w}_{\mathrm{l}}\right)$. The vector of unit cost functions is denoted by $\mathrm{c}(\mathbf{w})$ and the zero profit condition implies that $\mathbf{p}=\mathrm{c}(\mathbf{w})$, which means that the equilibrium factor price vector $\mathbf{w}$ is pinned down by the goods price vector $\mathbf{p}$. The balance of trade condition for trade in factor services can then be written as:

$$
\mathbf{w M}=0
$$

Similar to our discussion above, the market or social planner can now be thought of choosing a net factor import vector $\mathbf{M}$ that maximizes the direct factor trade utility function (3) subject to the balanced trade condition (4). The equilibrium net factor import vector $\mathbf{M}$ is then a function of $\mathbf{w}$ and $\mathbf{V}$, i.e. $\mathbf{M}=\mathrm{M}(\mathbf{w}, \mathbf{V})$.

So far we have viewed trade in factor services as a way of augmenting the country's endowment vector to maximize consumer utility. Alternatively, we can fix the level of consumer utility $\mathrm{u}$ and solve for net factor import vector $\mathbf{M}$ that enables the economy to attain this utility level at a minimum expenditure. This logic leads to the 
concept of a factor trade expenditure function where the factor trade utility function (3) defines the constraint and the left-hand side of (4) becomes the objective. The factor trade expenditure function gives then the minimum expenditure on factor services necessary to obtain the utility level u. Formally, it can be written as:

$$
\mathrm{e}(\mathbf{w}, \mathrm{u}, \mathbf{V})=\min \left\{\mathbf{w} \mathbf{M} ; \mathrm{U}^{\mathrm{f}}(\mathbf{M}, \mathbf{V}) \geq \mathrm{u}\right\} .
$$

Recall that the factor price vector $\mathbf{w}$ is pinned down by the exogenously given goods price vector $\mathbf{p}$ through the cost-price relationship, $\mathbf{p}=\mathrm{c}(\mathbf{w})$. As a result, $\mathbf{w}$ will capture the effects of international goods prices on the expenditures on factor services. Since the factor trade expenditure function embodies the equilibrium relationships between utility, factor prices and the factor content of trade it is the central tool for proving the autarky price formulation of the Heckscher-Ohlin Theorem. A key property of the factor trade expenditure function, similar to an expenditure function in consumer theory, is that it is increasing in utility, i.e. $\mathrm{e}\left(\mathbf{w}, \mathrm{u}^{1}\right) \geq \mathrm{e}\left(\mathbf{w}, \mathrm{u}^{0}\right)$ for $\mathrm{u}^{1}>\mathrm{u}^{0}$.

Consider now a comparison of the economy in an autarky and a free trade equilibrium. The autarky equilibrium is characterized by the autarky factor price vector $\mathbf{w}^{\mathbf{a}}$ and the autarky utility level $\mathrm{u}^{\mathrm{a}}$. In a free trade equilibrium the economy's factor price vector is given by $\mathbf{w}^{\mathbf{f}}$ and the free trade utility level is denoted by $u^{\mathrm{f}}$.

\section{General Heckscher-Ohlin Theorem:}

Assume that the economy experiences gains from trade, i.e. $u^{f}>u^{a}$. The autarky price vector $\boldsymbol{w}^{\boldsymbol{a}}$ imposes a restriction on the factor content of net imports under free trade, such that $\boldsymbol{w}^{a} \boldsymbol{M}\left(\boldsymbol{w}^{f}, u^{f}, \boldsymbol{V}\right) \geq 0$.

Proof: Since $\mathrm{u}^{\mathrm{a}}<\mathrm{u}^{\mathrm{f}}$ and the factor trade expenditure function is increasing in utility, we obtain $\mathbf{w}^{\mathrm{a}} \mathrm{M}\left(\mathbf{w}^{\mathrm{a}}, \mathrm{u}^{\mathrm{a}}, \mathbf{V}\right) \leq \mathbf{w}^{\mathrm{a}} \mathrm{M}\left(\mathbf{w}^{\mathrm{a}}, \mathrm{u}^{\mathrm{f}}, \mathbf{V}\right)$. Since $\mathrm{M}\left(\mathbf{w}^{\mathrm{a}}, \mathrm{u}^{\mathrm{f}}, \mathbf{V}\right)$ minimizes the expenditure of obtaining the free trade utility level $\mathrm{u}^{\mathrm{f}}$ implies that $\mathbf{w}^{\mathrm{a}} \mathrm{M}\left(\mathbf{w}^{\mathrm{a}}, \mathrm{u}^{\mathrm{f}}, \mathbf{V}\right) \leq \mathbf{w}^{\mathrm{a}} \mathrm{M}\left(\mathbf{w}^{\mathrm{f}}, \mathrm{u}^{\mathrm{f}}, \mathbf{V}\right)$. Under autarky, there is no trade and $\mathbf{M}\left(\mathbf{w}^{\mathrm{a}}, \mathrm{u}^{\mathrm{a}}, \mathbf{V}\right)$ is the zero vector. Consequently, $\mathbf{w}^{\mathbf{a}} \mathbf{M}\left(\mathbf{w}^{\mathbf{a}}, \mathrm{u}^{\mathrm{a}}, \mathbf{V}\right)=0$. But this implies that $\mathbf{w}^{\mathrm{a}} \mathbf{M}\left(\mathbf{w}^{\mathbf{f}}, \mathrm{u}^{\mathrm{f}}, \mathbf{V}\right) \geq 0$. 
Several comments are in order. First, $\mathbf{w}^{\mathrm{a}} \mathbf{M}\left(\mathbf{w}^{\mathrm{f}}, \mathrm{u}^{\mathrm{f}}, \mathbf{V}\right) \geq 0$ generalizes the two-factor formulation from the previous section to higher dimensions. However, if there are more than two factors, it is not possible to pinpoint which particular factor is exported or imported. Applying the balanced of trade $\mathbf{w}^{\mathbf{f}} \mathbf{M}\left(\mathbf{w}^{\mathbf{f}}, \mathrm{u}^{\mathrm{f}}, \mathbf{V}\right)=0$ to the restriction one obtains $\left(\mathbf{w}^{\mathbf{a}}-\mathbf{w}^{\mathbf{f}}\right) \mathrm{M}\left(\mathbf{w}^{\mathbf{f}}, \mathrm{u}^{\mathrm{f}}, \mathbf{V}\right) \geq 0$. The latter can be interpreted that the country will, on average, import factor services that have a high factor price relative to its trading partners and import factor services with a relatively low factor price.

Second, since $\mathbf{w}^{\mathbf{a}}$ imposes a restriction on the factor content of net imports $\mathbf{M}$, $\mathbf{w}^{\mathrm{a}} \mathbf{M}\left(\mathbf{w}^{\mathbf{f}}, \mathrm{u}^{\mathrm{f}}, \mathbf{V}\right) \geq 0$ constitutes a testable Heckscher-Ohlin hypothesis that can be refuted by the data. This is illustrated in Figure 2 where the economy's autarky factor price vector $\mathbf{w}^{\mathbf{a}}$ identifies a hyperplane which defines the set of net import vectors which is compatible with the prediction.

Third, an attractive feature of this formulation is that the existence of gains from trade is the only critical sufficient condition for the Heckscher-Ohlin theorem to hold. The deeper reasoning for this generality is that this formulation combines data from two equilibria: autarky and free trade. By contrast, Heckscher-Ohlin formulations which involve only data from a free trade equilibrium require strict symmetry assumptions on technologies and consumer preferences in order to generate predictions of how factor endowment differences affect trading patterns. As a result, there is quite a bit at stake in testing this general Heckscher-Ohlin formulation since a refutation of the prediction could not be accounted for by unmet assumptions on country symmetries regarding technologies or preferences.

\section{Empirical domain and data sources}

The case for using Japan's $19^{\text {th }}$ century opening up from almost complete autarky to open trade as a natural experiment to test comparative advantage trade theory has already been articulated in Bernhofen and Brown $(2004,2005)$. Since the Heckscher-Ohlin framework is a specific comparative advantage trade model, much of the justification for using the case of Japan developed in those two papers carries over to the test of the Heckscher-Ohlin model. The data requirements for such a test follow from the basic theoretical prediction about the positive sign of $\mathbf{w}^{\mathbf{a}} \mathbf{M}$ once it is recognized that $\mathbf{M}=\mathbf{A T}$, 
where $\mathbf{A}$ is the domestic technology matrix during the early free trade period and $\mathbf{T}$ is the vector of net imports. The vector of net imports $\mathbf{T}$, which was used in Bernhofen and Brown $(2004,2005)$, is readily available from published sources. Data quality issues that have yet to be resolved restrict $\mathbf{T}$ to the period from 1868 onwards. ${ }^{6}$ Japanese economic historians have compiled plausible estimates for most of the elements of $\mathbf{w}^{\mathbf{a}}$, and the following discussion provides more detail about the procedure used to complete it. A range of historical sources discussed below provide the elements for constructing the domestic technology matrix $\mathbf{A}$, which is the unit (net) factor demands during the free trade period.

The unique historical circumstances in the case of the Japanese opening up to trade allowed identification of a period of time over which the A matrix would have been reasonably stable for tradable goods: 1859 to the mid-1870s. Historical circumstances ensured that this was the case. It is plausible that rapid technological change in the production of tradable goods and in the infrastructure of the economy could have taken place in the years immediately following the opening up, which could have led to rapid changes in factor demands. For several reasons, the adoption of the new technologies of the industrial revolution in Japan only began in earnest after the mid-1870s. ${ }^{7}$ Most important, as Pauer(1987) notes, an immense gap in technological know-how and skills of its labor force existed between Japan and the western sources of new technologies at the time of its opening up. Adoption of western technologies by the private sector required it to overcome this gap, which took two decades or more under the best of circumstances. Transportation technologies, such as steamships or railroads, also required skills, organizational capabilities and capital that only became available during the second or third decade of the Meiji period. ${ }^{8}$ Finally, even incremental changes in organization using existing technology that could have influenced factor demands (for example, the creation of large-scale cocoon reeling establishments with mostly female

\footnotetext{
${ }^{6}$ Data on trade prior to 1868 are only available from the reports of the British consuls at the individual treaty reports. Unfortunately, the reports of the consuls do not record several key imports (particularly woolen and cotton cloth) in a consistent manner.

${ }^{7}$ The major exception to this rule would be limited application of new mining and metallurgy techniques during the early 1870 s in some government-owned mines.

${ }^{8}$ Unlike in Latin America, the Anglo-Saxon regions of recent settlement or colonial Africa, foreign capital played no role in the establishment and construction of modern transportation systems.
} 
labor) also emerged only slowly, and these are well-documented in the historical literature.

The need for stability of the A matrix and for reliable trade data thus restricts the temporal domain of the test to the years 1868 to 1875 . Before describing the data sources for the construction of $\mathbf{w}^{\mathbf{a}}$ and $\mathbf{A}$, we provide a short discussion of the pattern of endowments in the Japanese economy during Tokugawa period, which ended in 1868 (or about one decade after the opening up to international trade). The economic inheritance of the Tokugawa economy, particularly the technologies and organization of production, continued to play an important role through the nineteenth century [see Tanimoto (2006)].

\subsection{The Tokugawa economy: an endowment perspective}

The late Tokugawa economy was a well-articulated pre-modern economy with strong trading relationships among the main economic regions and evidence of significant regional specialization. At the same time, most goods that would enter into trade after the opening up in 1859 were produced in rural areas with the household as the production unit (see Saito and Tanimoto (2004)). Historians debate how successful the late Tokugawa economy was at overcoming two fundamental constraints: land scarcity and unproductive technologies. The opening up of trade may have been fundamental in relaxing both of these constraints. (Totman and American Council of Learned Societies., 1995) stresses the limits that Japan's geography placed on the resources available to it. His study of the lumber industry (Totman, 1995) highlights the more general ecological stress of Japan's land scarcity. Japan's topography essentially has only three gradients. A small percentage of the land area is flat land well-suited for rice and other crops. The plains are typically surrounded by diluvial terraces, which give way to steep mountains. The core traditional economic regions of Japan are at the heart of these plains (the Kinki (Osaka/Hyōgo/Kyoto), Nobi (Nagoya) and Kantō (Tokyo)). Additional outposts were Nagasaki on the island of Kyushu and port cities and fishing villages along the coast of the Sea of Japan and the Inland Sea. The remainder of the land area (about 80 percent) is a series of steep mountain ranges that run up and down the spine of all four main islands. Totman argues that by the early $18^{\text {th }}$ century, land scarcity dominated the Tokugawa economy in all resource-intensive areas of production, including agriculture, forestry and 
mining (Totman, 1995, ch.12). High demand for lumber (particularly after disastrous urban fires that followed in the wake of large earthquakes) led to classic Ricardian diminishing returns, as the lumber industry was forced to go ever deeper into the mountains to secure supplies (Totman, 1995a) and (Totman, 1995b). The most prominent adaptation to the scarcity of land was the development of a sophisticated fertilizer industry, which utilized waste organic materials from farms and the cities and drew upon sardine and herring resources available off of the northern island of Hokkaido. Techniques also adjusted with higher intensities of labor. Yasuba (1996, p. 545) argues that as a result of these developments, the Japanese economy "will have to be judged not to have suffered severely from a shortage of natural resources."

The other significant feature of Tokugawa Japan that receives attention in the historiography is the state of technological development. On the one hand, historians stress the ability of Japanese produces to develop and adopt new and sophisticated methods for production and organization. The history of innovation in the Japanese fisheries discussed in Kalland (1995) and Howell (1995), for example, points to considerable ingenuity in both the development of new nets and methods of organizing fishing. On the other hand, the cultural and economic isolation of Japan before 1859despite the access to Dutch writings on technology_meant that its technologies were unable to take advantage of developments in the substitution of mechanical action for human labor so prominent in the textile sector, advances in metallurgy or the application of inanimate power to drive machines or move earth. The technologies in place during the early period of open trade reflect these limitations.

This discussion of the construction of the A matrix for the late Tokugawa and early Meiji economies (that is, after the opening up of trade in 1859) will focus first on describing the kinds of sources that are available. It will then turn to the identification of the five main fundamental resources of this economy and two key intermediate goods: fertilizers and charcoal. The integration of the Tokugawa and early Meiji economies meant that production relationships (upstream and downstream) could be quite sophisticated, despite the fact that this was a pre-industrial economy closed off to a trickle of international trade. 
Japan's pattern of specialization after the opening up of trade enables ready calculation of the bulk of its factor exports. The pattern of imports is much more diverse, but significant progress can be made by focusing on two major foodstuffs (rice and beans), cotton and manufactures made of cotton and metals.

\subsection{Sources for the A matrix}

An initial look at the available sources would suggest some pessimism about the ability to reconstruct the factor requirements of a major set of products during the early years of international trade (1859 to 1875). The first survey of industrial production in Japan only took place in Meiji 7 (1874), and the first comprehensive census - which forms of the basis of reconstructions of Japan's national accounts - only took place in 1885. Nonetheless, a numerous sources exist that allow for a reasonable approximation to resource requirements. Most important, for much of the nineteenth century after 1859 (the opening up), the diffusion of new technologies into the Japanese economy was limited to a few readily identifiable sectors. Partly because they were so remarkable, the diffusion is well documented. Through the late $1880 \mathrm{~s}$, most of the economy operated with essentially the same technologies that were in use during the late Tokugawa era. For those sectors that experienced rapid technological change, contemporary documents and the reports of foreign visitors allow a ready assessment of the differences between the modern and traditional technologies. Overall, the technological legacy of the Tokugawa era dominated the production of traded goods during the first fifteen years of open trade.

We know less about the substitution of factors that may have occurred after the opening up, which may make data from traditional technologies that were in use after the opening up suspect. For the most prominent cases, such as the establishment of largerscale tea refining operations or businesses that specialized in the raising of cocoons, it appears that when factor substitution did take place, it also involved new forms of business organization. Fortunately, it is possible to check the results reached using technological data from the early Meiji period against sources that document actual factor requirements during the Tokugawa period. The discussion of the robustness of the estimates presented here includes this check where possible. 
The most important source for this study is the massive Nōji Chosa, a series of surveys of agricultural production statistics in Japanese prefectures. The survey took place during the late 1880s, and was reprinted in Chō, et. al. (1979) as a multi-volume set. The basis of the coverage is uneven. Some of the data cover particular villages and other cover counties of prefectures. Some are differentiated according to landlords or tenants. A majority of prefectures did not supply data. ${ }^{9}$ An important advantage of this source is its inclusion of all tradable agricultural products (with the exception of vegetable wax) and the astounding detail provided about inputs. Detail is available for all major productive tasks according to the days of labor needed, usually broken down by sex and always including the total cost of labor (from which sex can very often be inferred). For example, the data on tea production includes cultivating, fertilizing, picking and processing. The source provides detail on the weight and type of fertilizer for about twenty kinds of fertilizer. Information is provided on the amount of fixed and working capital used (often with an estimated rate of depreciation) and often on the types of capital used. Other inputs are also reproduced. Finally, the common practice was to record information on inputs per tan, a unit of areal measure equal to 300 tsubo or about one-tenth of a hectare. This source provided the starting point for all of the agricultural commodities found in the A matrix.

The observations of the agents of western governments, travelers and experts hired by the Japanese governments provide the second type of source for this study. The most famous of these is the memorandum written by the French mining engineer, Francisque Coignet, Note sur la richesse minerale du Japon (Coignet, et al., 1957), which provides detailed comparisons of the input requirements for all six stages of traditional copper mining, smelting and refining technologies. Three other examples include the reports by the American mining engineers Pumpelly and Lyman (Lyman, 1879 and Pumpelly, 1866) and the summary of conditions by the German engineer Netto (Netto, 1879). ${ }^{10}$ Several foreigner visitors and experts provided detailed reportage on the other main Japanese export industries. One example is de Bavier (1874). De Bavier was the

\footnotetext{
${ }^{9}$ Usable data prefectures is available from 19 out of 47 . These are scattered around Japan, but are most heavily concentrated in the western part of the country.

${ }^{10}$ Yoshiki (1979) provides an extended discussion of the reports of the activities of numerous western mining engineers employed to upgrade the technologies used in the Japanese mining industry.
} 
representative in Yokohama for one of the most important French importers of Japanese silks. American, British and Austrian observers also offered detailed accounting of production conditions in silk and tea over the late 1860 s to the early $1880 \mathrm{~s} .{ }^{11}$ Not all foreign observers had the detailed knowledge of de Bavier or Coignet, but they were accustomed to describing production conditions in terms of inputs used and outputs gained.

Japanese economic and business historians are primarily responsible for the final source for information on technologies and factor usage. Buried away in communal and other governmental archives and business and family papers are detailed accounts of production conditions for a range of industries. Historians have brought these materials together to provide a rich picture of the economic and commercial life of late Tokugawa and early Meiji Japan. Historians have also made use of a few of the han surveys of the middle $19^{\text {th }}$ century, which can also help to sort out the basic production conditions. ${ }^{12}$

A review of all of these materials suggests that as a first approximation, technologies of the late Tokugawa economy utilized five basic inputs: skilled male labor, unskilled male labor and female labor. Primarily found in urban areas, skilled labor was found in the traditional crafts and in some industries such as soy brewing. Satio (2005) provides estimates for evolution of skill premium, which was on the order of three or four to one during this period. Male unskilled labor was found in urban and rural areas. The $\mathbf{A}$ matrix developed here assigns most rural farm labor to the unskilled category, although certain activities in areas such as silk reeling would perhaps be best categorized as skilled. ${ }^{13}$ As Japanese economic historians have long recognized, much of rural production was carried out on a by-employment basis (for example, the spinning and weaving of yarn). Although this organization of production allowed the full employment of labor throughout the year, it may have diminished some of the gains accruing to specialization and mastering particular tasks. ${ }^{14}$ The final category of labor, female labor, most likely encompassed skilled and unskilled work. It also includes the work of young

${ }^{11}$ See (Adams (1870), Gribble (1883), Scherzer (1872), Syrski (1872) and Watson (1873).

${ }^{12} \mathrm{See}$, for example, the survey of the Chōsū han conducted in the early- to mid-1840s (Yamaguchi-ken Monjokan, 1960).

${ }^{13}$ See (Narita, et al. (1978) for a contemporary discussion of the skill requirements for raising silk. He argued that proper reeling required in excess of twenty to twenty-five years to fully master the skills required for this task.

${ }^{14}$ For a full exploration of this question, a comparison with the silk weaving industry may be in order. 
girls as well as women. As we will see, whether or not the work was primarily performed by women appears to be an important influence on the pattern of trade in factors of production.

The final two factors, land and capital, are treated in this study as homogenous inputs as a first approximation. Land is measured in terms of tan (about one-tenth of a hectare). Measuring of the input land does not distinguish between uplands and plains. The contribution of capital to costs of production is available for most products excepting some mining activities. Measurement also posed challenges, but the agricultural survey of the mid-1880s provides a great deal of detail on charges for maintenance of capital. Many other sources also provide either the charges to capital or the initial set-up costs (with implicit rates of depreciation) (Howell, 1995). The measured charges from this source have used the rate of depreciation prevailing in the 1870s and early $1880 \mathrm{~s}$, but have adjusted the implicit rate of interest upwards to reflect the higher cost of credit for rural industries during the pre-trade period. ${ }^{15}$ In any event, capital charges have all been converted to the buying power of the ryō of 1851-1853. (See the discussion of factor prices).

The technologies of the period involved three important intermediate inputs: fertilizer, wood and charcoal. By the early nineteenth century, the fertilizer industry included a supply chain that reached from Hokkaido through the Sea of Japan all the way to the Kinai region, which was the center of much of Japan's industry. Although the agricultural survey of the mid-1880s counted over twenty kinds of fertilizer, there were essentially four varieties used in Japan. The variety with a truly national market was fish fertilizer. Fish fertilizer made of sardines had been used substantially up through the $18^{\text {th }}$ century, but the opening of the southern part of the northern island of Hokkaido (and its settlement by the Matsumae clan) led to the development of a seasonal herring fishery. ${ }^{16}$ Herring was used both as a foodstuff and was also processed into fish fertilizer, which was then transported primarily to western Japan (the Kantō region relied much less on herring fertilizer). A second important source of fertilizer was human waste, which was

\footnotetext{
${ }^{15}$ Reported rates of depreciation ranged form three or four percent to much higher amounts, depending upon the capital good. Boats used in the seaweed industry, for example, lasted about three years. The standard interest charge appears to have been 10 percent. This has been adjusted upward to 12 percent for the pre-trade period.

${ }^{16}$ See (Howell (1995) and ,Nakanishi (1998).
} 
primarily available near large cities. Wastes from soybean oil, sake and rapeseed oil production constituted a third source that was available locally. Finally, Japanese farmers relied upon composted leaves from common forest land, rice husks and other materials. To summarize the resources embodied in these diverse fertilizers, equivalents per kan (equal to about $8.27 \mathrm{lbs}$.) of fish fertilizer were established using the relative price information available in the Nouji Chosa.

Smelting and refining activities (including camphor, sugar and oil) accounted for most of the industrial use of wood and charcoal. The discussion in Lyman(1879) and other sources notes that most supplies were acquired from the areas around smelters. Data on the productivity of labor and land for the production of wood and charcoal are readily available.

\subsection{Sources for autarky factor price vector $\boldsymbol{w}^{a}$}

Japanese and western economic historians (and contemporary observers) have provided a rich documentation of the prices for different kinds of labor. This paper relies heavily upon the work of Saito, which is summarized in his book, several journal articles and book chapters (Saito, 1998, Saito, 1998, Saito, 2005 and Saito, 1991). Saito has been able to document the rate of pay for male and female agricultural workers in both the Kinai and the Kantō regions. The rates of pay for urban unskilled workers are available for longer time periods from both Edo (Tokyo) and Osaka/Kyoto. The wages of skilled workers in urban areas can be inferred from various construction trades and other craft occupations, such as the sewing of tatami mats. For skilled workers in rural industries, a reassessment of the labor and wages paid in a soy sauce factory in Chosi provides an alternative estimate Suzuki(1990). For the initial calculations used in this paper, the wages for agricultural workers compiled from the records of landlords from near Osaka found in Saito (1973,Table 1) are used for male unskilled and female unskilled labor. The year used is 1851-1855. ${ }^{17}$ Most of the export and import-competing industries were based in rural areas, so that these wage series offer the best first approximation to wages paid unskilled workers. For skilled workers in these industries, who were found mostly in the

\footnotetext{
${ }^{17}$ The wage rates for women are similar to rates for women in the Lake Suwa region of the Nagano prefecture in eastern Japan in 1850 and 1854, but comparable rates for men are not available.
} 
mining and smelting sector, the urban skilled wage premium in a city such as Osaka of 5:1 probably overstates the skilled-unskilled premium. Within Tokyo, the ratio was a bit over $4: 1{ }^{18}$ The ratio of the annual salary plus in-kind payments of a skilled worker at the soy brewery in Chosi, a small town in the Kanto, to the contractual salaries for young men at the brewery and in the weaving district of Ashikagi, also located near Tokyo, provides an alternative. That ratio is $3.2: 1{ }^{19}$ The estimates used here assume a ratio of $3.2: 1$.

The valuation of land used several sources. Japanese farmland was assessed as rice tax based upon whether the land was dry or paddy land and on the rated quality. Gakkai.(1960 and,Uemura(1986) provide detailed data on land valuations on Shikoku (a southern island also known for growing sugar) and in the area around Ashikagi, which is 80 kilometers from Tokyo, for 74 groups of parcels over the period 1809 to 1858 .

Regression analysis of these data suggests that paddy land was valued at a slight premium over dryland; the main determinant of value was quality. In 1853, a tan of land would be valued at about 9 ryō. These data are roughly consistent with the report of Syrski on the valuation of land around Nagasaki ca. 1860 and a bit under the valuation Henderson (1975, pp. 64-65) provides for a paddy field in the Shiga Prefecture. ${ }^{20}$ The implicit rent charged on a property of a given value depended upon the use of the land. Syrski cites about 2 percent for rice fields and the data in the Nouiji Chosa Chō, et al.(1979) imply up to 8 to 10 percent for mulberry and tea. The estimates here assumed 8 percent, so that the annual implicit rent was 0.72 ryō.

The price of capital is the relevant interest rate plus depreciation times the value of the capital employed. For most of the industries discussed above, the relevant cost of capital was often (but not always) included along with a rate of depreciation and an interest rate. From the data for agricultural-based industries, the usual charge appears to have been listed as depreciation or interest. These charges ranged from two percent for rice to up to 8 to 10 percent for the export products, silk and tea. As a first approximation,

\footnotetext{
${ }^{18}$ The comparison uses the day wage of a laborer in Tokyo from Bunko(1989, for unskilled day workers) and the average for mid-skilled construction trades from Kenkyūkai(1937)

${ }^{19}$ See Gakkai.(1960, p. 257) for the contract information for young weavers in Ashikagi and Suzuki(1990) for the data on earnings at the soy brewery.

${ }^{20}$ See (Gribble, 1883, p. 10, Syrski, 1872, p. 199). The valuations are reported estimates for 1860 , the first year of open trade.
} 
the results presented here assume that the rural producers of all of these commodities faced an annual interest rate of twelve percent. As Toby and Saito note (Saito and Settsu, 2006 and Toby, 2004), actual interest rates paid by small-time producers varied according to a number of characteristics that the data at hand can not identify. Saito (2006, p. 10) cites the studies of Uemura and Nakmura that, despite showing diverging trends in the 1860 s and later, are consistent with Toby's finding of 12-15 percent in the 1840s for a village near Nagoya (in western Japan). ${ }^{21}$ The resulting charges for capital used in this study were up to 15 or 16 percent for industries such as silk and tea, where the reported maintenance charges were relatively high. Capital requirements are available for most products, either as the amount of capital or an annual charge. These requirements are expressed in terms of ryō of 1851-1853.

\section{Empirical results}

\subsection{Technology matrix}

A brief review of the elements of the A matrix (presented in Table 1) illustrates the net resource requirements of most of Japan's most important tradable goods. Note first of all that the matrix includes all intermediate input-output relationships reduced to their fundamental resource requirements. For some goods, these relationships could be rather intricate. Silk production required purchase or raising of cocoons, which in turn were raised from silkworm eggs usually purchased from an independent vendor. The raising of cocoons required mulberry leaves, which were in turn produced by specialized growers. The calculation of the final input requirements for silk required information about the productivity of silkworm eggs in terms of cocoons that could be raised, the required amount of mulberry leaves for raising cocoons and the productivity of cocoons in terms of reeled silk. The final production of some metals such as lead required knowledge of the resource requirements in the production of pig iron.

\footnotetext{
${ }^{21}$ All of these studies deal with provinces in western Japan. I am not aware of studies of rural interest rates that provide insight into rates in the rural Kantō.
} 
The relative importance of particular resources (such as female labor) could in the end depend upon substantial intensity in the production of an intermediate product. Cotton cloth production required yarns spun by female labor. The use of primarily female labor for the time-consuming task of picking cotton created a bias towards female labor that was present even before the cotton was ginned and sent to the market. Male miners dug out ore from the cramped tunnels or galleries typical of Japanese mines of the 1860s and early 1870 s, but women were often employed to wash the ores and break them (by hand) into small pieces for further processing.

The A matrix reveals the diversity of input usage for traded goods. The input usage reflects both the organization of production and assigning of tasks by sex (as well as skill level). Virtually all of the goods of an agricultural origin or using raw materials produced in agriculture were produced by peasant households or medium-sized farmers. ${ }^{22}$ The raising of silk cocoons was a time-intensive task that took place over a few short weeks. It required the labor of the entire family, which could result in relatively balanced use of male and female labor. Some tasks within the household were specialized by sex, including field tasks such as picking cotton or tea, the spinning of cotton yarn and the weaving of cotton cloth. More often than not, products that heavily used female labor would be produced in the home. ${ }^{23}$

As the A matrix illustrates, skilled labor was much more likely to be found in the mining and metallurgy sector, although skilled male labor was also critical for sorting tea prior to sale. Mines and smelting or refining operations were typically operated as a family firm or a government enterprise. Those in the private sector relied upon teams led by skilled miners, who were identifiable by either their wage or the description provided by the sources. ${ }^{24}$ It is also noticeable that if we recognize that 100 catties equal one picul,

\footnotetext{
${ }^{22}$ One exception may be the refining of sugarcane, which required more in capital equipment than would be typical for a peasant household. However, it should be noted that the fishing enterprises that supplied much of the fertilizer industry were essentially small businesses with access to credit markets.

${ }^{23}$ This comment excludes tea firing establishments, which were staffed almost entirely by women. It is also noteworthy that the emergence of many larger-scale production activities (for example, machine reeling establishments, cocoon raising firms or machine spinning) that were carried on outside of the home also relied heavily on child labor.

${ }^{24}$ By the mid-1870s, the threshold of 15 sen per day was used. This was particularly important for the mining and metallurgy industries.
} 
the resource requirements for soybeans were actually a bit higher than rice. Partly because of the use of fertilizer, cotton and tea required even more resources.

\subsection{Empirical findings}

Table 2 applies the technology matrix to commodity exports and imports for each year of the experimental window of 1868-1875. The beginning date of 1868 reflects the consistent recording of commodity trade data that began when the Meiji government began publication of customs statistics. ${ }^{25}$ The final year of this period marks the onset of the changes in transportation and production technologies for which the Meiji era is best known. By that time, elements of the technology matrix that would have been valid for the early trade period would need to be adjusted. ${ }^{26}$ The columns give the factor content of exports, imports and net imports. Although there is some variation across the years, the results are quite consistent regarding the pattern of factor service trade. Regarding the volume of factor service flows, a striking feature in the labor category is the high magnitude of female labour days embodied in both exports and imports.

Table 3 provides more detail on the incidence of factor services imports and exports by industry. It uses the average exports for the period 1868-1875.A striking feature is the relatively large embodied quantities of both female and unskilled male workers relative to skilled workers in both exports and imports. In many years, the country's land content of exports exceeds those of its imports. The quantity of female worker services embodied in imports is also always larger than in exports. The large volume of net imports of female workers suggests that international trade relieved some of the pressure on the domestic female labor supply. Two-thirds of the imports of female labor services were concentrated in cotton textiles. Imports of the factor services of male unskilled male labor were concentrated in rice and sugar. .

\footnotetext{
${ }^{25}$ See the extended discussion in Sugiyama (1988) about the relative accuracy of the statistics presented in the British consular reports compared with those of the Meiji government. By the early 1870 s, the discrepancies between the two sources were minimal. The Meiji statistics have the advantage of providing consistent measures for the woolen and cotton cloths, which were important imports during the early trade period.

${ }^{26}$ For example, Tamura (2004) describes the emergence of a Japanese woolen industry in response to the importation of woolens and worsteds during the early free trade period. Tanimoto (1998) provides a similar discussion of the adaptation of the cotton textile industry.
} 
The finding for the factor land appears to be inconsistent with earlier speculations in the literature. In several years, land embodied in exports always exceeds land embodied in imports. In one test year, capital services are are on net exported. ${ }^{27}$

Given our previous discussion of the importance of labor in overall production, we could on empirical grounds ignore capital and land and lump female and unskilled male labor into a single "unskilled labor" category. This would allow us to compare, in the spirit of Leontief(1953), aggregate factor intensity ratios of Japanese exports and imports in terms of the ratio of skilled to unskilled labor. ${ }^{28}$ The data in Table 2 imply then that the ratio of skilled to unskilled labour for Japan's exports is higher than for its imports in every year. However, since the last column in Table 2 shows that Japan is a net exporter of skilled labor and a net importer of unskilled labor, one might be tempted to argue that Japan was abundant in skilled labour and scarce in unskilled labor. This line of reasoning would mirror the Leontief paradox since the largely rural Japan of 1860 was arguably relatively abundant in unskilled labour relative to its advanced - and much more urbanized - trading partners in the west. ${ }^{29}$

As in the case of Leontief's exercise, it is inappropriate to infer relative factor abundance from observed patterns of factor service flows. This is particularly true if factor service flows are calculated using the domestic technology matrix in a world of dissimilar technologies. Since Japan's technology matrix is applied to both its exports and imports, column two (for exports) in Table 2 gives the "actual" factor services of exports. By contrast, column three (for imports) gives the counterfactual factor services that would have been necessary to produce the imported goods with domestic production techniques. Japan imported goods such as iron, steel, cotton cloth and yarn that it produced with techniques that were relatively intensive in unskilled labour, whereas its

\footnotetext{
${ }^{27}$ This result is not consistent with Williamson (1998, p. 18), who argues that Japan's imports were landand capital-intensive and its exports were labor-intensive (but see below). Yasuba (1996), by contrast, suggests that the export of primary products such as silk and tea reflects land-intensive exports. The two years (1870 and 1871) that saw the highest embodied imports of land were also years of exceptionally poor rice harvests.

${ }^{28}$ Applying the US technology matrix for 1947 to US exports and imports with the rest of the world, Leontief (1953) found that the capital-labour ratio of US exports was higher than that of its imports. Since the US was the most capital abundant country at the time, this finding has been named the Leontief paradox. ${ }^{29}$ Despite the large population of Tokyo, only 16 percent of Japan's population lived in urban areas as late as 1880, compared with 24 percent for continental Europe and over 60 percent for the United Kingdom (Bairoch, 1988, Table 18.1).
} 
western trading partners (particularly Great Britain) produced those goods using machine - or capital — intensive techniques. The relatively high volume of female workers and unskilled male workers embodied in the country's imports reveal the higher labour-intensity of its production technologies.

\subsection{Test results}

A proper evaluation of whether the observed pattern of trade follows the logic of the Heckscher-Ohlin theory requires an evaluation of $\mathbf{w}^{\mathbf{a}} \mathbf{A T}$. Table 4 contains the autarky price values of Japan's exports, imports and net imports for each of the trading years 1868-1875. The main results, i.e. the sign of the inner product $\mathbf{w}^{\mathbf{a}} \mathbf{A T}$, are reported in the last row of the table. The sign is positive for each of the trading years. So far, the findings provide strong evidence for the Heckscher-Ohlin hypothesis. Two additional robustness checks further strengthen these results.

First, the trading vector $\mathbf{T}$ used in the analysis includes about 92 percent of exports, but only 61 percent of the imports by value during the test period. Of the excluded imports, about 2.5 percent were military items for which comparable information on Japanese technologies is not available. Another 6.3 percent were western goods not produced in Japan or goods lacking detail on quantity. ${ }^{30}$ About 20 percent were woolens, which amounted to 6 million yards in the early 1870s and over 22 million yards by 1875 . Recent research (Jenkins, 1988; Sugiyama, 1988; Tamura,2001 and Tamura, 2004) provides valuable insights into the extent to which imports of woolens, particularly worsted cloths, substituted for Japanese silks in traditional Japanese dress. ${ }^{31}$ Mixed cotton-woolen cloths such as orleans, mousselines de laine, lustres, and merinos took the place of silk cloths such as habutai (a plain weave fabric), obi (cloth for belts or sashes) and chirimen (a silk crepe fabric). The imports were used for belts, linings for sleeves, collars and other elements of traditional Japanese dress. The same sources note that many imports of cotton cloth (which were for the most part lighter than Japanese cotton cloths) served this purpose as well. The woolen cloths that were clearly identifiable as substitutes

\footnotetext{
${ }^{30}$ The top three in this category were machines and instruments, leather and leather goods (boots and shoes) and glass. Most of the machinery imports were on behalf of the Meiji government during this period.. ${ }^{31}$ Western dress would have required the use of heavier woolen cloths.
} 
for Japanese silks accounted for about 75 to 80 percent of the yardage of and about 55 percent of the value. of imported woolens. ${ }^{32}$ Japanese and French-language sources provide enough information to reconstruct the dimensions of these fabrics and the input requirements for them. The main source of disagreement in the literature is over the extent to which women were weaving these cloths by the early open trade period. This study follows the approach of the contemporary French silk trader, de Bavier, who argued that women wove most habutai and chirimen; men and women would have been both involved in the weaving of belts. ${ }^{33}$ Panel A includes imputed input requirements for woolen imports for which clear substitutes in the silk sector were identifiable. Panel B offers an alternative calculation for wAT that includes the woolens that substituted for Japanese silks. The alternative raises the value of wAT by 1.1 to over 3 million ryō. Because of data limitations, about 30 percent of Japanese imports are not accounted for even in the revised calculations.

The second robustness check is required because during some of the $1870 \mathrm{~s}$, the Japanese economy experienced a trade deficit. The deficit could lead to a violation of the condition of balanced trade in resources required by the theoretical model. Private capital flows could not fill the gap, since Japan prohibited direct foreign investment. The government's recourse to international credit markets was limited to a few modest loans in the early 1870s. As a result, exports of gold and silver bullion and coin covered the deficit in goods trade. One approach to ascertaining whether the exports of gold and silver were sufficient to offset the estimated value of wAT is to construct estimates of the domestic resources embodied in the outflow of specie. Lyman's study tour of mining in the late 1870s included several private gold and silver mines that used traditional technologies (the Seigano mine) and the government-owned Ikuno gold and silver mine, which introduced western technologies for mining and smelting in the mid-1870s. Lyman

\footnotetext{
${ }^{32}$ United States consular reports from the treaty ports in 1870 and 1875 provide more detail on imports than the published Meiji trade statistics. They confirmed that virtually all goods classified as mixed woolen and cotton goods were actually cloths such as orleans, mousseline de laines, lustres and fancies. The calculation excludes woolen blankets, which were substitutes for traditional Japanese comforters (stuffed with cotton wadding and a silke cover). It also excludes the import category unenumerated woolen piece goods, which could have also included substitutes for domestically-produced silks.

${ }^{33}$ See Bavier(1874) and Ichikawa(1996) for more information. Porter and National Association of Manufacturers (U.S.)(1898, p.76) provides details on habutai production, which by the 1890s became important as a source for silk used in the manufacture of umbrellas.
} 
argued that the Seigano gold and silver mine was most likely still operational only because the mine included tracts of land that provided wood for the charcoal used for smelting and because the owner was able to retain his small older and loyal labor force of 81 workers for relatively low wages. Investments in Western technologies at the government-owned Ikuno mine, which employed 925, included steam engines for pumping out water, transporting ore (to allow access to deeper mining) and stamping the ore as well as reverbatory furnaces. These investments increased the efficiency of the mining and recovery of precious metals from ore. The input requirements per ounce for gold and silver produced at the Seigano and Ikuno mines are found in panel A of Table 6. The low productivity of the Seigano mine's ores, the use of charcoal for smelting and the small batches for each charge of the smelters meant that almost 50 days of labor were required to produce one ounce of refined gold and 5 days for one ounce of silver. The application of capital-intensive western mining and smelting techniques could boost labor productivity at mines such as the Ikuno mine by two and one-half times over traditional techniques. The Ikuno mine was the largest producer of gold and the second-largest producer of silver in Japan during the period Netto(1879, Table II).

Data on the net outflows of gold and silver (in yen) are available for the years 1873 to 1875 (see Tōyō Keizai Shinpōsha. and Ishibashi,1935). If valued at prices prevailing in world markets at the time, the highest outflow (in 1875) was about 486 thousand ounces of gold and 2.8 million ounces of silver. ${ }^{34}$ Using the estimates from the capital-intensive Ikuno mines, the outflow was 0.5 to 2 million ryō, or one-tenth to onethird of the estimated value of wAT when we account for the resource cost of the imports of woolens. If the valuation uses the the labor- and charcoal-intensive technologies prevailing at the Seigano mine, the implicit outflow would be 15 to 70 percent of wAT when adjusted for the resource cost of woolens. Both robustness checks suggest that the general result stands: the Heckscher-Ohlin theorem in its most general form holds in this crucial test case.

\footnotetext{
${ }^{34}$ Japanese production of gold was 13,000 ounces in 1874 . The production of silver was 344,000 ounces. See Plunkett(1875, p. 459).
} 


\section{Concluding remarks}

This paper provides an initial test of the general validity of the Heckscher-Ohlin Theorem as first formulated by Deardorff (1982) and then generalized by Neary and Schweinberger (1986). Since this formulation is based on the gains from trade -or reevealed preference logic- a test of it requires compatible data of an economy operating under both autarky and free trade. For this purpose, we have constructed a unique historical data set that meets two restrictions imposed by the theoretical framework: autarky factor price data as a measure of relative factor scarcity and plausible stability in unit factor demands during the period of free trade. The dataset draws upon the economic history of Japan over the period 1850 to 1875 . Until 1859, Japan was essentially in autarky. After Japan opened up to international trade, its trade expanded rapidly. The autarky period in Japan provides information on relative factor abundance that is based upon market prices, not quantities. The early period of open trade offers abundant evidence on the technologies used to produce both exports and import-competing goods. Japan's state of technological knowledge, its infrastructure and the lack of relevant skills in its labor force meant that the adaptation of alternative, western-based technologies was a slow process that only got underway during the late 1870s; the matrix of input demands would have changed little.

The interaction of factor demands and trade flows suggests the surprising result that from a quantitative perspective, capital and land played minor roles in Japan's trade in factors. Instead, when measured using only domestic technologies, Japan was at times a net exporter of land and a net importer of female and unskilled labor. A preliminary conjecture is that this pattern reflected both differences in relative resource abundance and technologies between Japan and its major trading partners. This conjecture has implications for the interpretation of the pattern of trade during the first globalisation, which will be pursued in subsequent research.

The preliminary test of the general Heckscher-Ohlin theorem confirmed the basic proposition that under conditions of gains from trade, relative factor scarcity is predictive of the pattern of trade. This result applies across a wider range of empirical domains than previous tests of the Heckscher-Ohlin theorem, including cases of non-homothetic preferences and dissimilar technologies. Both of these conditions characterize the 
international economy of the $19^{\text {th }}$ century and perhaps in the globalised economy of the $21^{\text {st }}$. 


\section{References}

Adams. "Report by Mr. Adams, Secretary to Her Majesty's Legation in Japan on the Central Silk Districts of Japan." 353-71, 1870.

Atkinson, R. W. "The Chemistry of Sake Brewing." Memoirs of the Science Department Tokio Daigaku (University of Tokyo) no. No. 6 (1881).

Bavier, Ernest de. La Sériciculture : Le Commerce Des Soies Et Des Graines Et L'industrie De La Soie Au Japon. Lyon Milan: H. Georg ; Du Molard frères, 1874.

Bairoch, Paul. Cities and Economic Development : From the Dawn of History to the Present. Chicago: University of Chicago Press, 1988.

Bernhofen, Daniel M. "On predictability in the neoclassical trade model: a synthesis". Forthcoming in Economic Theory.

Bernhofen, Daniel. M., and John C. Brown. "A Direct Test of the Theory of Comparative Advantage: The Case of Japan". Journal of Political Economy 112, no. 1 (2004): 48-67.

Bernhofen, Daniel M., and John C. Brown. "An Empirical Assessment of the Comparative Advantage Gains from Trade: Evidence from Japan." American Economic Review 95, no. 1 (2005): 208-25.

Bowen, Harry P., Edward E. Leamer, and Leo Sveikauskas. "Multicountry, Multifactor Tests of the Factor Abundance Theory." American Economic Review 77, no. 5 (1987): 791-809.

Bunko, Mitsui. Kinsei Kōki Ni Okeru Shuyō Bukka No Dōtai. Zōho kaitei. ed. Tōkyō: Tōkyō Daigaku Shuppankai, 1989.

Chō, Yukio, Ken'ichirō Shōda, and Hiroshi Ōhashi. Meiji Chūki Sangyō Undō Shiryō Tōkyō: Nihon Keizai Hyōronsha, 1979.

Coignet, Francisque,. Nihon Kōbutsu Shigen Ni Kansuru Oboegaki : Ikuno Ginzan Kensetsuki. Translated by Junkichi Ishikawa. [Tōkyō] : Sangyō Keizai Shinbunsha 1957.

Davis, Donald R., and David E. Weinstein. "An Account of Global Factor Trade." American Economic Review 91, no. 5 (2001): 1423-53.

Deardorff, Alan V. "The General Validity of the Heckscher-Ohlin Theorem." American Economic Review 72, no. 4 (1982): 683-94.

Gakkai., Waseda Daigaku. Keizaishi. Ashikaga Orimono Shi. Ashikaga: Ashikaga Sen i Dōgyōkai, 1960.

Gribble, Henry. "The Preparation of Japanese Tea." Transactions of the Asiatic Society of Japan 12, no. 1 (1883): 1-87.

Hauser, William. Economic Institutional Change in Tokugawa Japan: Osaka and the Kinai Cotton Trade. London: Cambridge University Press, 1974.

Hayek, Friedrich A. von. "The Use of knowledge in Society." American Economic Review 35 (1945), 519-30.

Henderson, Dan Fenno comp. Village "Contracts" In Tokugawa Japan : Fifty Specimens with English Translations and Comments, Asian Law Series ;; No. 2;. Seattle: University of Washington Press, 1975.

Howell, David Luke. Capitalism from within Economy, Society, and the State in a Japanese Fishery. Berkeley: University of California Press, 1995. 
Ichikawa, Takamasa. Nihon Nōson Kōgyōshi Kenkyū : Kiryū Ashikaga Orimonogyō No Bunseki. Dai 1-han. ed. Tōkyō: Bunshindō, 1996.

Ichiro, Takahashi. "Wrought Iron from the Traditonal Tatara Furnace." In History of Industry and Technology of Japan, edited by Erich Pauer, 137-52, 1995.

Itoh, Motoshige, and Masayuki Tanimoto. "Rural Entrepreneurs in the Cotton-Weaving Industry of Japan." In: Toward the Rural-Based Development of Commerce and Industry: Selected Experiences from East Asia; 47-68; Edi Learning Resources Series. Washington, D.C.: World Bank, edited by Yujiro Hayami, 1998.

Japan. Ōkurashō. Shuzeikyoku. Dai Nihon Gaikoku Bōeki Nijūgonen Taishōhyō : Meiji Gannen Yori Dō Nijūgonen Ni Itaru. Tōkyō: Koide Yoshifusa, 1893.

Japan. Rinji Hakurankai Jimukyoku (Chicago Exposition 1893). "Naikoku Kangyō Hakurankai Shinsa Hyōgo." In Meiji zenki sangyō hattatsushi shiryō : Kangyō hakurankai shiryō ; 191. Tōkyō Meiji Bunken Shiryō Kankōkai, 1975.

Jenkins, D T. "The Response of the European Textile Manufacturers to the Opening of the Japanese Market." Textile History 19, no. 2 (1988): 255-78.

Kalland, Arne. Fishing Villages in Tokugawa Japan, Nordic Institute of Asian Studies Monograph Series. Richmond, Surrey: Curzon Press, 1995.

Kasuga, Yutaka. "Transfer and Development of the Coal Mine Industry in Hokkaido." In HSDP-JE Series. Tokyo: United Nations University, 1982.

Leontief, Wassily. Domestic production and foreign trade: The American capital position re-examined. Proceedings of the American Philosophical Society 97 no.4 (1953): 332-349.

Lyman, Benjamin Smith. Geological Survey of Japan: Reports of Progress for 1878 and 1879. Tookei: Public Works Department, 1879.

Meade, J. E. A Geometry of International Trade. London: Allen \& Unwin, 1952.

Nakanishi, Satoru. Kinsei Kindai Nihon No Shijō Kōzō : "Matsumae Nishin" Hiryō Torihiki No Kenkyū Shohan.. ed. Tōkyō: Tōkyō Daigaku Shuppankai , 1998.

Narita, Shisai, Kanrei Koyana, Kinzaburō Igarashi and Hiroshi Ishiyama. Kogai Kinuburui Taisei, Edo Kagaku Koten Sōsho ; 14. Tōkyō: Kōwa Shuppan, 1978.

Neary, J. Peter, and Albert G. Schweinberger. "Factor Content Functions and the Theory of International Trade." Review of Economic Studies 53, no. 3 (1986): 421-32.

Netto, C. On Mining and Mines in Japan [Microform], Memoirs of the Science Department, University of Tokio, Japan. Tokyo, Japan: The University, 1879.

Oka, Mitsuo, and Ryūzō Yamazaki. Nihon Keizaishi : Bakuhan Taisei No Keizai Kōzō .Shohan. ed. Kyōto: Mineruva Shobō, 1983.

Pauer, Erich. "Traditional Technology and Its Impact on Japan's Industry During the Early Period of the Industrial Revolution." Economic Studies Quarterly 38, no. 4 (1987): 354-71.

Plunkett, F. R. "Report by Mr. Plunkett on the Mines of Japan." In House of Commons Sessional Papers, 465-519, 1875.

Porter, Robert P., and National Association of Manufacturers (U.S.). Commerce and Industries of Japan : A Report of Investigations Conducted by Robert P. Porter, Circular of Information of the National Association of Manufacturers of the United States of America ; No. 11 [2nd Ed.] April, 1898. Philadelphia: Bureau of Publicity National Association of Manufacturers, 1898. 
Pumpelly, Raphael. Geological Researches in China, Mongolia, and Japan, During the Years 1862-1865, Smithsonian Contributions to Knowledge. [Vol. Xv, Art. 4]. [Washington,: Smithsonian institution, 1866.

Saito, Osamu. "Edo Shichyu Ni Okeru Service Gyo Chingin: 1775-1871 (Wage of Service Industry in Edo)." Nihon Rekishi 430 (1998): 81-85.

. "The Labor Market in Tokugawa Japan: Wage Differentials and the Real Wage Level, 1727-1830." In Japanese Economic History, 1600-1960. Volume 6. The Japanese Economy in the Tokugawa Era, 1600-1868; 266-82; New York and London: Garland, edited by Michael Smitka, 1998.

. "Movements of Agricultural Wage Rates in Japan." Shakai-Keizai-Shigaku 32, no. 2 (1973): 50-69.

. "Wages, Inequality, and Pre-Industrial Growth in Japan, 1727-1894." edited by Robert C. Allen, Tommy Bengtsson and Martin Dribe. Oxford and New York: Oxford University Press, 2005.

-. "Women's Labor in Agricultural Development--Japan's Historical Experience (in Japanese )." Economic Review (Keizai Kenkyu) 42, no. 1 (1991): 31-41.

Saito, Osamu, and Tokihiko Settsu. "Money, Credit and Smithian Growth in Tokugawa Japan." Tokyo: Hitotsubashi University, 2006.

Saito, Osamu, and Masayuki Tanimoto. "The Transformation of Traditional Industries." In The Economic History of Japan: 1600-1990. Volume 1. Emergence of Economic Society in Japan, 1600-1859; pp. 268-300; Oxford and New York: Oxford University Press, edited by Akira Hayami, Osamu Saito and Ronald P. Toby, 2004.

Scherzer, Karl. Fachmännische Berichte Über Die Österreichisch-Ungarische Expedition Nach Siam, China Und Japan (1868-1871.). Stuttgart,: J. Maier, 1872.

Shinbo, Hiroshi. Kinsei No Bukka to Keizai Hatten : Zen Kōgyōka Shakai E No Sūryōteki Sekkin. Tōkyō: Tōyō Keizai Shinpōsha, 1978.

Sugiyama, Shinya. "Textile Marketing in East Asia, 1860-1914." Textile History 19, no. 2 (1988): 279-98. . Japan's Industrialization in the World Economy, 1859-1899 : Export Trade and Overseas Competition. London; Atlantic Highlands, NJ: Athlone Press, 1988.

Suzuki, Yuriko. "Shōyu Seizōgyō Ni Okeru Kōyō Rōdō'." In Shōyu Jōzōgyōshi No Kenkyū, edited by Reiko Hayashi, 131-96. Tōkyō: Yoshikawa Kōbunkan, 1990.

Syrski, S. "Landwirtschaft in Japan." In Fachmännische Berichte Über Die Österreichisch-Ungarische Expedition Nach Siam, China Und Japan (18681871.), edited by Karl Scherzer, 175-227. Stuttgart: Julius Maier, 1872. . "Über Seidenkultur in Japan." In Fachmännische Berichte Über Die Österreichisch-Ungarische Expedition Nach Siam, China Und Japan (18681871.) edited by Karl Scherzer, 228-86. Stuttgart: Julius Maier, 1872.

Takeda, Haruhito. Nihon Sandōgyōshi. Shohan. ed. Tōkyō: Tōkyō Daigaku Shuppankai, 1987.

Tamura, Hitoshi. Fasshon No Shakai Keizaishi : Zairai Orimonogyō No Gijutsu Kakushin to Ryūkō Shijō. Tōkyō: Nihon Keizai Hyōronsha, 2004.

. "The Technological Development of Textile Production Centers in Early Meiji Japan (1870s to 1880s): A Case Study of the Socio-Economic Impact of the 
Fashion for Woollen Textiles from Western Europe." Shakai-Keizai-Shigaku 67, no. 4 (2001): 23-48.

Tanimoto, Masayuki. "The Evolution of Indigenous Cotton Textile Manufacture before and after the Opening of the Ports." Japanese Yearbook of Business History 9 (1992): 30-56.

Tanimoto, Masayuki. "The Role of Tradition in Japan's Industrialization: Another Path to Industrialization." In The Role of Tradition in Japan's Industrialization: Another Path to Industrialization; 3-44; Japanese Studies in Economic and Social History, Vol. 2. Oxford and New York: Oxford University Press, edited by Masayuki Tanimoto, 2006.

Toby, Ronald P. "Country Bankers in Proto-Industrial Japan: The Transformation of Credit." In The Economic History of Japan: 1600-1990. Volume 1. Emergence of Economic Society in Japan, 1600-1859; 301-36; Oxford and New York: Oxford University Press, edited by Akira Hayami, Osamu Saito and Ronald P. Toby, 2004.

Totman, Conrad. The Lumber Industry in Early Modern Japan: Honolulu Univ. of Hawaii Press, 1995.

Totman, Conrad D., and American Council of Learned Societies. Early Modern Japan. Berkeley: University of California Press, 1995.

Tōyō Keizai Shinpōsha., and Tanzan Ishibashi. Nihon Bōeki Seiran. Tōkyō: [Tōyō Keizai Shinpōsha], 1935.

Uchida, Hoshimi. "Narrow Cotton Stripes and Their Substitutes." Textile History 19, no. 2 (1988): 159-70.

Uemura, Shōji. Kinsei Nōson Ni Okeru Shijō Keizai No Tenkai. Shohan. ed. Tōkyō: Dōbunkan, 1986.

Vanek, Jaroslav. "The Factor Proportions Theory: The N-Factor Case." Kyklos 21, no. 4 (1968): 749-56.

Wada, Tsunashirō. The Mining Industry of Japan During the Last Twenty Five Years, 1867-1892 [Microform]. Tokyo: Printed at the Tokyo Tsukiji Type Foundry, 1893.

Watson. "Reports on the Production of Tea in Japan." In British Parliamentary Papers, 1873.

Williamson, Jeffrey G. "Globalization, Factor Prices and Living Standards in Asia before 1940." In Asia Pacific Dynamism, 1550-2000, edited by A. J. H. Latham and Heita Kawakatsu, 13-46. London, New York: Routledge, 2000.

Woodland, Alan D. "Direct and Indirect Trade Utility Functions." Review of Economic Studies 47, no. 5 (1980): 907-26.

Yamaguchi-ken Monjokan.Bōchō Fūdo Chūshin'an.Yamaguchi: Yamaguchi-ken Monjokan,1960.

Yoshiki, Fumio. "Metal Mining and Foreign Employees." The Developing Economies 14, no. 4 (1979): 484-505. 
Figure 1: Heckscher-Ohlin prediction in the 2-factor case

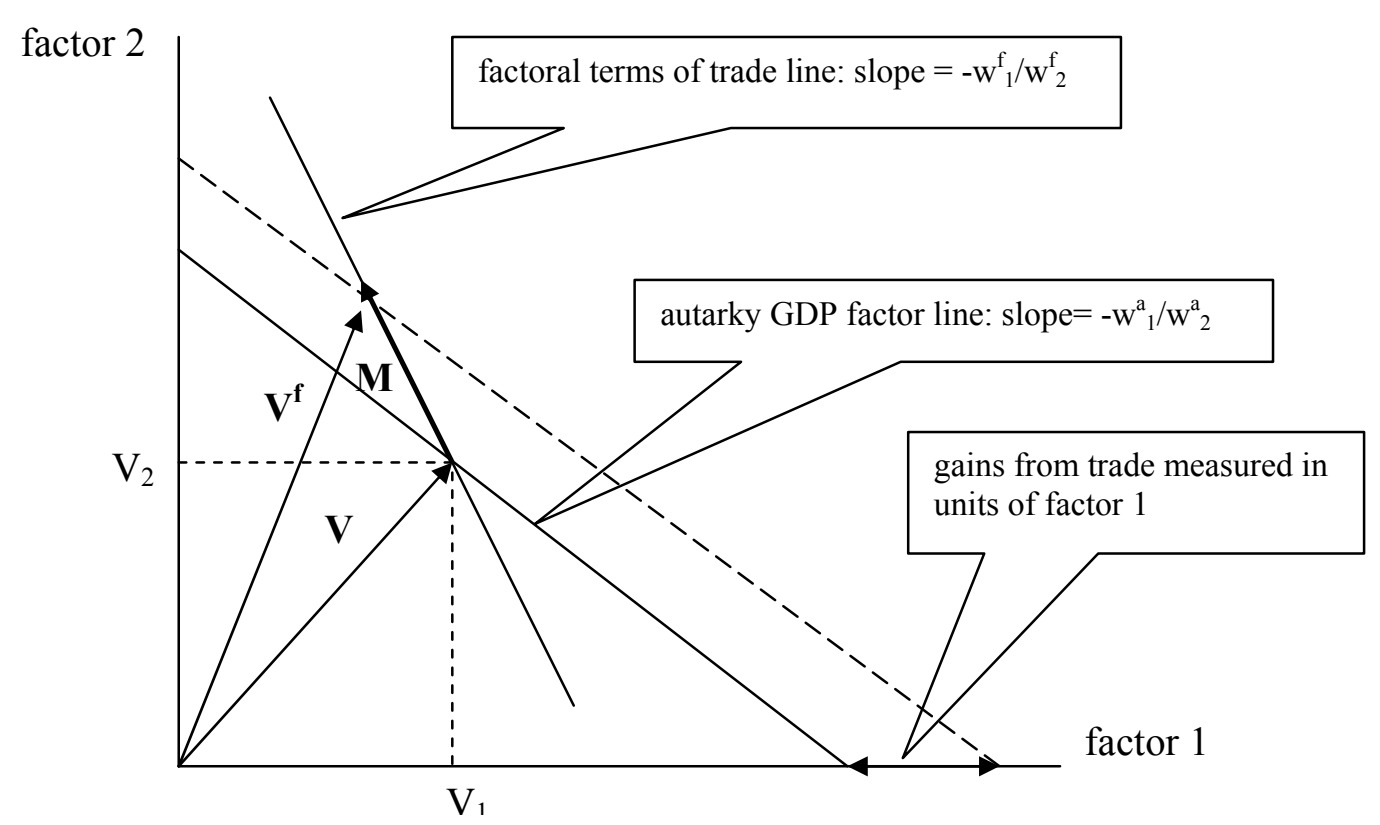


Figure 2: General Heckscher-Ohlin prediction

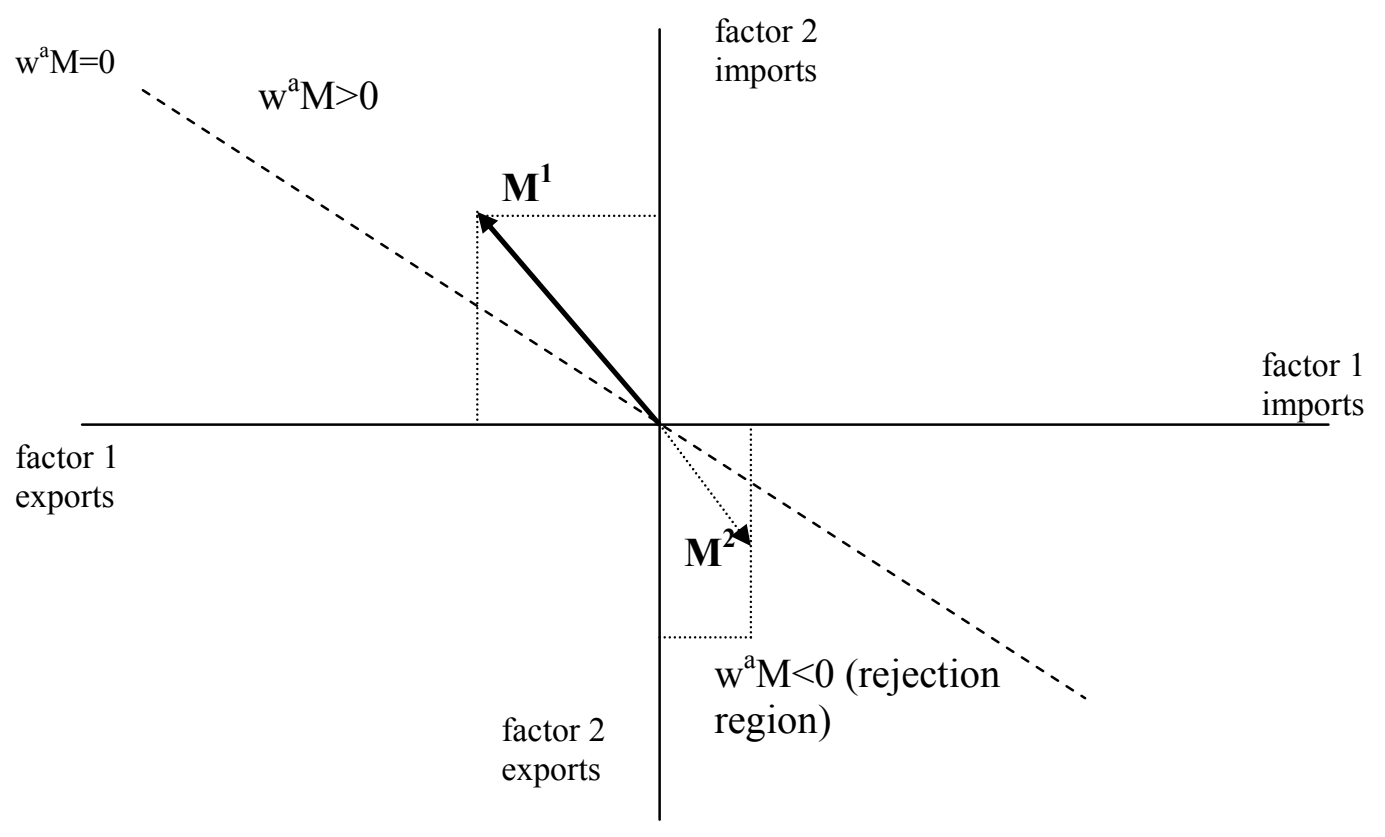


Table 1: A Matrix for Japan ca. 1870

\begin{tabular}{|c|c|c|c|c|c|c|}
\hline Exports & Share & $\begin{array}{r}\text { Male } \\
\text { skilled } \\
\text { labor } \\
\text { (days) }\end{array}$ & $\begin{array}{r}\text { Male } \\
\text { unskilled } \\
\text { labor } \\
\text { (days) }\end{array}$ & $\begin{array}{r}\text { Female } \\
\text { labor } \\
\text { (days) } \\
\end{array}$ & $\begin{array}{r}\text { Capital } \\
(\text { ryō) } \\
\end{array}$ & $\begin{array}{r}\text { Land } \\
(\tan )\end{array}$ \\
\hline \multicolumn{7}{|l|}{$\begin{array}{l}\text { Silkworm eggs } \\
\text { and pierced }\end{array}$} \\
\hline cocoons & 16.89 & 66.9 & 997.9 & 500.6 & 151.9 & 22.7 \\
\hline Silk & 34.12 & 676.6 & $12,777.2$ & $16,564.0$ & $2,813.5$ & 390.7 \\
\hline Silk waste & 1.51 & 135.3 & $2,555.4$ & $3,312.8$ & 562.7 & 78.1 \\
\hline Tea & 27.77 & 409.8 & 456.1 & 208.4 & 145.1 & 22.9 \\
\hline Bancha tea & 0.58 & 0.0 & 183.0 & 107.4 & 4.0 & 0.0 \\
\hline Wheat & 0.11 & 0.0 & 131.5 & 24.2 & 9.7 & 8.1 \\
\hline \multirow[t]{2}{*}{ Tobacco } & 0.85 & 0.0 & 360.3 & 27.4 & 12.4 & 10.3 \\
\hline & 0.71 & 0.0 & 397.0 & 261.4 & 18.4 & 33.0 \\
\hline Vegetable Wax & 1.17 & 0.0 & 375.2 & 0.0 & 30.1 & 0.0 \\
\hline Mushrooms & 1.17 & 0.0 & 967.7 & 0.0 & 0.0 & $1,240.6$ \\
\hline Seaweed & 2.01 & 14.7 & 29.4 & 44.1 & 5.7 & 0.2 \\
\hline Cut Seaweed & 0.52 & 1.6 & 78.5 & 80.1 & 0.6 & 0.0 \\
\hline $\begin{array}{l}\text { Kanten (Agar- } \\
\text { agar) }\end{array}$ & 0.62 & 49.6 & 1505.1 & 148.7 & 19.2 & 0.6 \\
\hline Copper products & 2.97 & 546.0 & 537.7 & 58.4 & 5.7 & 12.6 \\
\hline Charcoal & 0.01 & 73.2 & 132.3 & 0.0 & 0.8 & 3.4 \\
\hline Coal & 1.23 & $6,045.0$ & $2,542.0$ & 38.4 & 37.7 & 321.2 \\
\hline Sulphur & 0.09 & 21.5 & 0.0 & 0.0 & 8.8 & 3.5 \\
\hline Total & 92.32 & & & & & \\
\hline \multicolumn{7}{|l|}{ Imports } \\
\hline Rice & 9.99 & 0.0 & $4,662.8$ & 634.3 & 138.6 & 188.4 \\
\hline Soy & 1.33 & 0.0 & 43.5 & 11.2 & 1.9 & 4.0 \\
\hline Wheat & 0.02 & 0.0 & 59.8 & 11.0 & 4.4 & 3.7 \\
\hline Indigo & 0.04 & 0.0 & 102.8 & 51.1 & 46.1 & 2.7 \\
\hline Kerosene & 0.71 & 23.2 & 238.0 & 0.0 & 12.4 & 6.4 \\
\hline Lead & 0.45 & 545.8 & 404.4 & 498.8 & 14.3 & 0.0 \\
\hline Tin & 0.06 & $1,887.2$ & 188.3 & 0.0 & 0.3 & 4.0 \\
\hline Pig iron & 0.11 & 145.0 & 73.0 & 0.0 & 0.5 & 1.6 \\
\hline Refined Iron & 2.58 & 233.6 & 100.5 & 0.0 & 21.7 & 2.2 \\
\hline Steel & 0.07 & 211.9 & 103.9 & 0.0 & 0.0 & 4.0 \\
\hline Brown Sugar & 6.69 & 10.6 & 130.3 & 20.1 & 53.3 & 1.9 \\
\hline White Sugar & 2.86 & 31.7 & 274.3 & 38.2 & 2.4 & 12.3 \\
\hline Raw Cotton & 2.08 & 0.0 & 274.5 & 258.4 & 24.8 & 10.9 \\
\hline Cotton Yarn & 14.57 & 0.0 & 317.8 & $2,708.0$ & 28.7 & 12.6 \\
\hline \multicolumn{7}{|l|}{ Unfinished } \\
\hline $\begin{array}{l}\text { Cotton Cloth (100 } \\
\text { yards) }\end{array}$ & 1.89 & 0.0 & 2.4 & 39.0 & 0.2 & 0.1 \\
\hline Finished Cotton & 7.59 & 12.6 & 2.4 & 39.0 & 0.2 & 0.1 \\
\hline
\end{tabular}


Cloth (100 yards)

Total Share of

Imports

61.02

Notes: All resource requirements are per metric ton unless otherwise specified. The ryō was the gold-based currency of Tokugawa Japan (during the period of autarky). One tan is about one-tent of a hectare.

Sources: For a detailed discussion of the sources, please see the Data Appendix. 
Table 2: Japan's Net Factor Imports: 1868-1875 (AT)

\begin{tabular}{|c|c|c|c|}
\hline & Exports & Imports & $\begin{array}{r}\text { Net factor } \\
\text { imports }\end{array}$ \\
\hline \multicolumn{4}{|l|}{1868} \\
\hline Labor male skilled (days) & 2.60 & 3.91 & 1.31 \\
\hline Labor male unskilled (days) & 13.47 & 11.86 & -1.61 \\
\hline Labor female (days) & 13.46 & 41.63 & 28.16 \\
\hline Capital (ryō) & 2.84 & 1.77 & -1.07 \\
\hline Land $(\tan )$ & 0.69 & 0.36 & -0.32 \\
\hline \multicolumn{4}{|l|}{1869} \\
\hline Labor male skilled (days) & 2.43 & 5.59 & 3.16 \\
\hline Labor male unskilled (days) & 10.11 & 26.49 & 16.38 \\
\hline Labor female (days) & 9.55 & 45.94 & 36.39 \\
\hline Capital (ryō) & 2.06 & 2.76 & 0.70 \\
\hline Land (tan) & 0.55 & 1.03 & 0.47 \\
\hline \multicolumn{4}{|l|}{1870} \\
\hline Labor male skilled (days) & 3.76 & 6.58 & 2.82 \\
\hline Labor male unskilled (days) & 11.45 & 57.35 & 45.90 \\
\hline Labor female (days) & 9.80 & 76.05 & 66.25 \\
\hline Capital (ryō) & 2.38 & 5.76 & 3.38 \\
\hline Land (tan) & 0.73 & 2.18 & 1.45 \\
\hline \multicolumn{4}{|l|}{1871} \\
\hline Labor male skilled (days) & 5.91 & 5.54 & -0.37 \\
\hline Labor male unskilled (days) & 18.33 & 47.99 & 29.66 \\
\hline Labor female (days) & 16.68 & 84.49 & 67.81 \\
\hline Capital (ryō) & 3.69 & 5.38 & 1.70 \\
\hline Land (tan) & 0.74 & 1.70 & 0.96 \\
\hline \multicolumn{4}{|l|}{1872} \\
\hline Labor male skilled (days) & 6.62 & 6.30 & -0.32 \\
\hline Labor male unskilled (days) & 16.62 & 19.12 & 2.50 \\
\hline Labor female (days) & 12.73 & 92.64 & 79.91 \\
\hline Capital (ryō) & 3.00 & 3.46 & 0.47 \\
\hline Land (tan) & 0.92 & 0.60 & -0.32 \\
\hline \multicolumn{4}{|l|}{1873} \\
\hline Labor male skilled (days) & 4.67 & 8.59 & 3.92 \\
\hline Labor male unskilled (days) & 15.66 & 19.11 & 3.46 \\
\hline Labor female (days) & 13.19 & 90.12 & 76.93 \\
\hline Capital (ryō) & 2.93 & 3.84 & 0.91 \\
\hline Land $(\tan )$ & 0.88 & 0.59 & -0.28 \\
\hline \multicolumn{4}{|l|}{1874} \\
\hline Labor male skilled (days) & 7.07 & 11.22 & 4.16 \\
\hline Labor male unskilled (days) & 18.16 & 25.94 & 7.77 \\
\hline Labor female (days) & 14.08 & 105.53 & 91.45 \\
\hline Capital (ryō) & 3.76 & 5.01 & 1.25 \\
\hline Land (tan) & 1.04 & 0.77 & -0.27 \\
\hline
\end{tabular}




\begin{tabular}{lrrr}
\hline 1875 & & & \\
Labor male skilled (days) & 6.71 & 16.02 & 9.31 \\
Labor male unskilled (days) & 17.42 & 30.91 & 13.49 \\
Labor female (days) & 13.93 & 105.18 & 91.25 \\
Capital (ryō) & 3.70 & 6.16 & 2.46 \\
Land (tan) & 1.08 & 0.87 & -0.20 \\
\hline
\end{tabular}

Notes: The net factor trade is AT, where $\mathrm{T}=($ Imports-Exports). All values are expressed in millions.

Source: Trade data from the Meiji trade statistics. See the data appendix for the sources of data for the A matrix. 
Table 3: The Factor Content of Trade (in millions)

\begin{tabular}{|c|c|c|c|c|c|c|}
\hline Exports & Share & $\begin{array}{l}\text { Male } \\
\text { skilled } \\
\text { labor } \\
\text { (days) }\end{array}$ & $\begin{array}{c}\text { Male } \\
\text { unskilled } \\
\text { labor } \\
\text { (days) }\end{array}$ & $\begin{array}{c}\text { Female } \\
\text { labor } \\
\text { (days) }\end{array}$ & $\begin{array}{c}\text { Capital } \\
\text { (ryō) }\end{array}$ & $\begin{array}{l}\text { Land } \\
(\tan )\end{array}$ \\
\hline \multicolumn{7}{|l|}{$\begin{array}{l}\text { Silkworm eggs } \\
\text { and pierced }\end{array}$} \\
\hline Silk & $\begin{array}{l}10.89 \\
34.12\end{array}$ & 0.40 & $\begin{array}{l}0.10 \\
7.47\end{array}$ & $\begin{array}{l}0.30 \\
9.68\end{array}$ & $\begin{array}{l}0.12 \\
1.64\end{array}$ & 0.23 \\
\hline Silk waste & 1.51 & 0.02 & 0.29 & 0.38 & 0.06 & 0.01 \\
\hline Tea & 27.77 & 3.10 & 3.45 & 1.58 & 1.10 & 0.17 \\
\hline Bancha tea & 0.58 & 0.00 & 0.14 & 0.08 & 0.00 & 0.00 \\
\hline Wheat & 0.11 & 0.00 & 0.09 & 0.02 & 0.01 & 0.01 \\
\hline Tobacco & 0.85 & 0.00 & 0.36 & 0.03 & 0.01 & 0.01 \\
\hline Camphor & 0.71 & 0.00 & 0.20 & 0.13 & 0.01 & 0.02 \\
\hline Vegetable Wax & 1.17 & 0.00 & 0.30 & 0.00 & 0.02 & 0.00 \\
\hline Mushrooms & 1.17 & 0.00 & 0.26 & 0.00 & 0.00 & 0.33 \\
\hline Seaweed & 2.01 & 0.13 & 0.26 & 0.39 & 0.05 & 0.00 \\
\hline Cut Seaweed & 0.52 & 0.00 & 0.11 & 0.12 & 0.00 & 0.00 \\
\hline $\begin{array}{l}\text { Kanten (Agar- } \\
\text { agar) }\end{array}$ & 0.62 & 0.01 & 0.35 & 0.03 & 0.00 & 0.00 \\
\hline Copper products & 2.97 & 0.98 & 0.97 & 0.11 & 0.01 & 0.02 \\
\hline Charcoal & 0.01 & 0.02 & 0.04 & 0.00 & 0.00 & 0.00 \\
\hline Coal & 1.23 & 0.26 & 0.11 & 0.00 & 0.00 & 0.01 \\
\hline Sulphur & 0.09 & 0.01 & 0.00 & 0.00 & 0.00 & 0.00 \\
\hline $\begin{array}{l}\text { Total } \\
\text { Imports }\end{array}$ & 92.32 & 4.98 & 15.15 & 12.93 & 3.05 & 0.83 \\
\hline Rice & 0.00 & 0.00 & 8.64 & 1.18 & 0.26 & 0.35 \\
\hline Soy & 0.00 & 0.00 & 0.82 & 0.21 & 0.04 & 0.08 \\
\hline Wheat & 0.00 & 0.00 & 0.01 & 0.00 & 0.00 & 0.00 \\
\hline Indigo & 0.00 & 0.00 & 0.00 & 0.00 & 0.00 & 0.00 \\
\hline Kerosene & 0.02 & 0.02 & 0.23 & 0.00 & 0.01 & 0.01 \\
\hline Lead & 0.89 & 0.89 & 0.66 & 0.81 & 0.02 & 0.00 \\
\hline Tin & 0.12 & 0.12 & 0.01 & 0.00 & 0.00 & 0.00 \\
\hline Pig iron & 0.30 & 0.30 & 0.15 & 0.00 & 0.00 & 0.00 \\
\hline Refined Iron & 3.67 & 3.67 & 1.58 & 0.00 & 0.34 & 0.03 \\
\hline Steel & 0.07 & 0.07 & 0.04 & 0.00 & 0.00 & 0.00 \\
\hline Brown Sugar & 0.57 & 0.57 & 7.04 & 1.08 & 2.88 & 0.10 \\
\hline White Sugar & 0.36 & 0.36 & 3.13 & 0.44 & 0.03 & 0.14 \\
\hline Raw Cotton & 0.00 & 0.00 & 1.03 & 0.97 & 0.09 & 0.04 \\
\hline Cotton Yarn & 0.00 & 0.00 & 3.86 & 32.88 & 0.35 & 0.15 \\
\hline Unfinished & & & & & & \\
\hline $\begin{array}{l}\text { Cotton Cloth (100 } \\
\text { yards) } \\
\text { Finished Cotton }\end{array}$ & 0.00 & 0.00 & 2.26 & 36.57 & 0.21 & 0.09 \\
\hline Cloth (100 yards) & 3.90 & 1.95 & 0.37 & 6.05 & 0.04 & 0.01 \\
\hline
\end{tabular}


Note: Exports and imports of factor services are based on averages for 1868-1875. Source: The A matrix and the Meiji trade statistics. 
Table 4: The Autarky Value of Japan's Factor Trade in the Early Years of Open Trade (in thousands of gold ryō (w $\left.{ }^{\mathrm{a}} \mathrm{AT}\right)$ )

\begin{tabular}{lccccccccc}
\hline & $\begin{array}{c}\text { Factor } \\
\text { Price ca. } \\
\text { 1851-1853 }\end{array}$ & 1868 & 1869 & 1870 & 1871 & 1872 & 1873 & 1874 & 1875 \\
\hline Exports & & & & & & & & & \\
Labor male skilled & 0.09 & 224 & 210 & 325 & 511 & 572 & 403 & 611 & 580 \\
Labor male & 0.03 & 364 & 273 & 309 & 495 & 449 & 423 & 490 & 470 \\
Labor female & 0.02 & 242 & 172 & 176 & 300 & 229 & 237 & 253 & 251 \\
Capital (per unit) & 0.24 & 692 & 500 & 580 & 897 & 729 & 714 & 915 & 901 \\
Land (per tan) & 0.72 & 495 & 399 & 526 & 535 & 662 & 630 & 747 & 777 \\
Total (waX) & & 2017 & 1554 & 1916 & 2737 & 2641 & 1777 & 2269 & 2202 \\
\hline Imports & & & & & & & & & \\
Labor male skilled & 0.09 & 338 & 483 & 569 & 479 & 544 & 742 & 970 & 1384 \\
Labor male & 0.03 & 320 & 715 & 1548 & 1296 & 516 & 516 & 700 & 835 \\
Labor female & 0.02 & 749 & 827 & 1369 & 1521 & 1668 & 1622 & 1900 & 1893 \\
Capital (per unit) & 0.24 & 431 & 672 & 1401 & 1310 & 843 & 935 & 1218 & 1499 \\
Land (per tan) & 0.72 & 261 & 739 & 1568 & 1227 & 431 & 426 & 554 & 630 \\
Total (w AM) & & 2099 & 3436 & 6455 & 5832 & 4002 & 4241 & 5341 & 6241 \\
\hline Imports-Exports & & & & & & & & & \\
Labor male skilled & 0.09 & 113 & 273 & 244 & -32 & -28 & 339 & 359 & 804 \\
Labor male & 0.03 & -43 & 442 & 1239 & 801 & 68 & 93 & 210 & 364 \\
Labor female & 0.02 & 507 & 655 & 1193 & 1220 & 1438 & 1385 & 1646 & 1643 \\
Capital (per unit) & 0.24 & -260 & 171 & 822 & 413 & 114 & 221 & 303 & 597 \\
Land (per tan) & 0.72 & -234 & 340 & 1042 & 692 & -231 & -204 & -193 & -147 \\
Total Net (w ${ }^{a} \mathbf{A T}$ ) & & 82 & 1882 & 4539 & 3095 & 1361 & 2464 & 3072 & 4038 \\
\hline
\end{tabular}

Notes: All values are in gold ryō. The value in each row is the net valuation of the trade in that factor at factor prices prevailing under autarky (1851-1853). For a discussion of the valuation of factors of production, please see the text. 
Table 5: The Impact of Woolen Imports and Exports of Gold and Silver

Panel A: Input Requirements for Woolen Cloths, Gold and Silver

\begin{tabular}{lccccc}
\hline Product & $\begin{array}{l}\text { Male } \\
\text { skilled } \\
\text { labor } \\
\text { (days) }\end{array}$ & $\begin{array}{l}\text { Male } \\
\text { unskilled } \\
\text { labor } \\
\text { (days) }\end{array}$ & $\begin{array}{l}\text { Female } \\
\text { labor } \\
\text { (days) }\end{array}$ & $\begin{array}{l}\text { Capital } \\
\text { (ryō) }\end{array}$ & $\begin{array}{l}\text { Land } \\
\text { (tan) }\end{array}$ \\
\hline Woolen cloths (per 100 yards) & 59.4 & 14.4 & 61.3 & 3.8 & 0.4 \\
Gold (Traditional) (per ounce) & 47.2 & 2.3 & 0.0 & 0.0 & 1.0 \\
Gold (Western) (per ounce) & 20.7 & 2.3 & 0.0 & 7.6 & 1.0 \\
Silver (Traditional) (per ounce) & 5.2 & 0.3 & 0.0 & 0.0 & 0.0 \\
Silver (Western) (per ounce) & 2.2 & 0.3 & 0.0 & 0.8 & 0.0 \\
\hline
\end{tabular}

Panel B: Alternative calculations of $\mathrm{w}^{\mathrm{a}} \mathrm{AT}$ (in thousands of gold ryō)

\begin{tabular}{|c|c|c|c|c|c|c|c|c|}
\hline $\begin{array}{l}\text { Autarky Value at factor } \\
\text { prices in } 1851-1853\end{array}$ & 1868 & 1869 & 1870 & 1871 & 1872 & 1873 & 1874 & 1875 \\
\hline $\begin{array}{l}\text { Total Net }\left(\mathrm{w}^{\mathrm{a}} \mathbf{A T}\right)(\text { from } \\
\text { Table 4) }\end{array}$ & 82 & 1882 & 4539 & 3095 & 1361 & 2464 & 3072 & 4038 \\
\hline $\begin{array}{l}\mathrm{w}^{\mathrm{a}} \mathbf{A T} \text { with Woolen } \\
\text { Cloths } \\
\mathrm{w}^{\mathrm{a}} \mathbf{A T} \text { with Gold and }\end{array}$ & 1139 & 2509 & 5473 & 4150 & 2936 & 5251 & 5009 & 7503 \\
\hline $\begin{array}{l}\text { Silver Net Exports } \\
\text { (Traditional } \\
\text { Technology) } \\
\text { w }^{\mathrm{a}} \mathbf{A T} \text { with Gold and }\end{array}$ & & & & & & 4550 & 1313 & 3658 \\
\hline $\begin{array}{l}\text { Silver Net Exports } \\
\text { (Western Technology) }\end{array}$ & & & & & & 2006 & 641 & 1502 \\
\hline
\end{tabular}

Notes: For a discussion of the calculations, please see the text.

Source: Bavier(1874, pp. 126-127), Porter and National Association of Manufacturers (U.S.)(1898, p. 76) and Ichikawa(1996, pp. 108-110) for the input requirements for chirimen, habutai and obi silk cloths.

Jenkins(1988,Sugiyama(1988,Tamura(2004,Tamura(2001) provided data on the equivalence between imported woolen cloths and domestically produced silks. Lyman(1879, pp. 43-45 and 160-162) provides the input requirements for gold and silver mining. Tōyō Keizai Shinpōsha. and Ishibashi(1935)) provides the data on net exports of gold and silver coin and bullion. 


\section{Data Appendix for construction of the A matrix}

This discussion of the data sources for the A matrix is divided according to each product. The discussion is broken down according to agricultural products (materials), agricultural products (food) and mineral products. The first category includes sericulture and related products and raw cotton and cotton textiles. The second category includes tea, rice, soybeans, brown sugar and white sugar. The final category includes coal, lead, tin, copper (refined), pig iron and iron manufactures.

\section{Sericulture}

Sericulture involves four separate products: mulberry leaves, silkworm eggs, cocoons and raw silk (reeled from cocoons). Several sources provide details about the interrelationship among these products and some information on resource use. ${ }^{35}$ By the end of the Tokugawa era, the raising of mulberry leaves and of silkworm eggs had become separate enterprises with some degree of regional specialization. During the early trade period, cocoons were raised by individual households within the home using household labor. There were only a few of the larger-scale cocoon-raising establishments, which seem to have become more widespread during the 1880 s and later. Where the cocoons were raised had important implications for the division of labor. Within the household, it would be a mix of male and female labor. In specialized cocoon-raising establishments, the labor was primarily younger women with an overseer. The technology matrix used here assumes that cocoons were raised by peasant households. Finally, during the early trade period, silk reeling using hand methods continued to dominate.

Chō, et al. (1979) provides the most detail on resource use in multiple volumes dedicated to the results of surveys carried out by prefecture (or by county, or gun). Not all prefectures were important sources of silk production and by no means is the coverage of the agricultural survey complete. Based upon the discussion of de Bavier (1874), the prefectures for which data were available and which are also more important for silk production were included in the analysis. They included Aomori, Akita, Yamagata and Yamanashi prefectures for mulberry leaves, cocoon raising and the production of

\footnotetext{
${ }^{35}$ Adams (1870), Bavier (1874), Syrski (1872).
} 
silkworm eggs. The reeling of silk also took place for the most part within peasant households using hand methods during the early period of open trade. ${ }^{36}$ By the mid-1880s (the period of the agricultural surveys), machine reeling was diffusing rapidly, although most Japanese silk was still reeled using hand methods. These calculations used only data from respondents to the survey who explicitly stated they were using hand methods. This consideration necessarily broadened the scope of included prefectures; for silk reeling, the study included Osaka, Hyōgo, Tottori, Ehime, Oita, Nagaski and Aomori prefectures. Most of these prefectures lie outside of the classic central silk producing region, but data from these areas would be more likely to capture the productivity of reeling using hand methods.

\section{Cotton and cotton textiles}

The main source for cotton production was Chō, et al. (1979). The prefectures included for the study are from the western part of Japan, which was the main cotton producing area. The prefectures included in the analysis were Ehime, Hiroshima, Tottori and Yamaguchi. Fortunately, the average productivity per tan was similar to the average productivity found for the cotton-growing areas of the Kinai, which was the center of production for the best-known cottons during Tokugawa Japan Hauser (1974,Table 14 on p. 124). Hauser (1974, pp. 130-131) also provided estimates of fish fertilizer in kan per tan, which were used in placed of the data found in the survey. Japanese cotton competed with the ginned imported cotton. For that reason, the estimates for Japan include the labor cost of ginning. Hauser (1974, p. 131) argues that one kan of seed cotton yielded 390 momme (or 39 percent) of ginned cotton. Cotton was typically ginned on the farm using hand methods. The estimates here assume that one-half day of labor was needed to gin one kan of cotton. ${ }^{37}$

Cotton yarn was a significant import during the early years of trading. Yarn was produced in the household using primarily female labor. ${ }^{38}$ There are a range of estimates

\footnotetext{
${ }^{36}$ The preliminary estimation of the factor content of trade excluded the small amount of cocoons (waste and pierced) and noshi and floss silk that was also exported. These products were essentially joint products of the main output. To account for these products in the resource usage of silk producers, the quantity of output has been adjusted upwards by the ratio of the total value of output to the value of output for firstquality silk products.

${ }^{37}$ One kan is $8.27 \mathrm{lbs}$. or $3.75 \mathrm{~kg}$. The estimate is from Hauser (1974, Table 28 on p. 163).

${ }^{38}$ See Itoh and Tanimoto (1998) for an extended discussion of the structure of the cotton textile industry during the late Tokugawa and early open trade periods.
} 
of productivity found in Hauser (1974), Tanimoto (1992) and Uchida (1988). The productivity did depend to some extent on the weight of the yarn. Productivity estimates in these sources range from 0.03 to $0.15 \mathrm{kan}$ of yarn per day. The estimates used here are from Tanimoto (1992, p. 40), where it was estimated that a spinner could spin about 100 momme of yarn in about two days. ${ }^{39}$

Weaving requires both preparation of the warp as well actual time for weaving. The same sources listed above provide some estimates of weaving productivity, although it should be noted that since Uchida's study was of domestic cotton striped cloth — which tended to be much heavier than the bulk of imported cloths (shirtings) - may underestimate the relevant productivity. Here there is much more agreement between Hauser and Tanimoto. ${ }^{40}$ The estimates used here assume one day per tan and another day for preparation.

Finally, data on finishing cloth (including the cost of dyes and other materials) is much more difficult to come by. We know that dyers tended to be specialized in that activity rather work at it as a by-employment, which was the case with spinners and weavers. Uchida (1988, p. 162) estimates the contribution the costs of dyeing yarn to the cost of cotton striped cloth at about 6.8 momme. At an estimated wage of 2 momme per day, that would yield a daily productivity of $0.3 \tan$. Evidence from the villages in the Chōshu Han would suggest a daily productivity of 0.73 tan. This higher productivity was assumed to apply to the labor component of all finished cloth. ${ }^{41}$

Tea

Tea was Japan's second most important export after the products of sericulture. Contemporary discussion by foreign observers of the Japanese tea industry included Syrski (1872) and Gribble (1883, Watson (1873). All three sources provide substantial detail about the steps involved in the growing and preparation of Japanese tea for export. In addition, the data fromChō, et al. (1979) are very useful. Tea is a heterogenous

\footnotetext{
${ }^{39}$ Given the wide variation in estimated productivities (and also for different cloths that were woven), this issue requires further research.

${ }^{40}$ Hauser (1974, p. 138) estimates that a weaver could produce up to one tan of cloth per day. Tanimoto (1992, pp. 40 and 45) suggests about one tan per day for a weaver in the Toyama and Nagano prefectures and from 1-2 tan per day depending upon the skill level for a weaver in the district of Izumi (near Osaka). ${ }^{41}$ The ample evidence on the indigo and other dyestuffs industries should allow some refinement of these rough estimates. Finished cloth was a little above one-tenth the yardage of all imported cotton cloth during the period of analysis.
} 
commodity, with widely varying resource requirements depending upon the quality of the final product. Most exported Japanese tea was green tea, which was dried in the countryside and then received some drying in the export port (Nagasaki or Yokohoma) prior to packaging and shipment. Based upon the per unit value from the export statistics, data from Hyōgo, Hiroshima, Oita and Sagea prefectures was used along with Gribble (1883). The labor requirements for fertilizing and cultivating came from the agricultural survey evidence, as did the data on capital, land and fertilizers. Gribble (1883, p. 8) provides a helpful breakdown of the productivity of (female) labor in picking tea and in the (skilled) labor used in the sorting and refining processes. Watson (1873, pp. 11-13 and 19) provides data on the labor requirements for the tea firing establishments in the port cities. $^{42}$

Rice

As the staple Japanese grain, data on rice production was available from fourteen of the prefectures covered by Chō, et al. (1979). Surprisingly, production conditions were relatively reasonably uniform across the country. The coefficient of variation of land productivity was, for example, only 0.22 . The coefficient of variation of male labor requirements was only a bit more. To convert the production data, which was by volume (koku), into the weight equivalent, Atkinson (1881) provided reasonable equivalents. ${ }^{43}$ These estimates did not assume double-cropping in a year.

Soy Bean

Legumes constituted an important import during some of the early years of Meiji. Since the export data do not distinguish among legumes, soybeans were chosen to stand in for all field beans in terms of determining the amount of resources embodied in imports. Chō, et al. (1979) provides data on soybean production for nine prefectures, which were used to construct the elements of the A matrix pertaining to legumes. The United States Department of Agriculture's conversion of volume to weight suggest that

\footnotetext{
${ }^{42}$ Chō, et al. (1979) also includes data on the production of bancha (coarse) tea. Japan's exports of bancha tea were about one-tenth of the exports of higher quality green teas.

${ }^{43}$ The measure of rice used in export statistics was by weight (picul, or $133.33 \mathrm{lbs}$.).
} 
there are 0.772 kilograms of soybeans to one liter. This implies about 23 catties per to, which is the conversion factor used in the analysis of the agricultural survey data. Brown and White Sugar

Japan's sugar production was confined to the eastern and southernmost areas of the archipelago. Two sources are available for estimating the resource requirements for raw cane production and the refining of sugar cane into brown and white sugar. The data from the agricultural survey (Chō, et al. (1979)) for Ehime, Nagasaki and Osaka were used to calculate resource requirements for sugar cane. Data from the Sanuki Han (on Shikoku) from Meiji 4 offer detail on the costs of refining sugar cane into brown sugar Oka, et al. (1983). The process for grinding sugar cane used power from a cow or other animal to power a mill; the boiling of the cane used firewood and charcoal. Refining brown sugar into white sugar required additional firewood and more labor for bleaching. The source for these added resource requirements is Uemura.

\section{Mineral Products}

Estimating the resource requirements of mineral products presents its own challenges. Japan possessed relatively abundant deposits of copper and silver ore, which were heavily mined during the Tokugawa period. Japanese mining technology and metallurgy posed significant barriers for taking full advantage of these deposits (see Netto (1879) for a classic statement of the deficiencies from the perspective of a German mining engineer). By the end of the Tokugawa era, the constraints of Japanese mining techniques meant that most productive deposits of ores bearing copper, silver and gold had already been heavily mined and output was quite limited. This came about for several reasons. Areas with mineral deposits were not mined by one firm. Instead, individual miners received contracts to mine subareas of a deposit. Mining technology did not use powder (not to speak of steam power) to excavate mine shafts, so that the dimensions of mine shafts were often very narrow with low ceilings. Japanese pumping technology was for the most part limited to hand pumps, which would require a large area as well as massive amounts of labor to pump areas prone to flooding. These technological constraints meant that mined areas were typically confined to veins that were close to the surface. The scale of mining was thus quite limited. Western engineers visiting Japan remarked on the honeycombed appearance of what had once been productive mining 
deposits. The dressing of ores occasionally used water power, but most often female labor without any inanimate power. The transport of ores was usually by coolie labor and only occasionally by horses. Perhaps because many mines cam under direct government ownership after the Meiji Restoration, mining experienced some of the earliest technological improvements using western methods of any Japanese industry. The $1870 \mathrm{~s}$ - the second part of the early trade period — were at the beginning of a period of transition, and accounts of mines from time reveal improvements in some parts of the operation (more often than not, gathering ores) and traditional Japanese technologies in others. For the data used in the A matrix, mining, smelting and refining operations have been chosen that continued to adhere to traditional technology.

Traditional Japanese metallurgy also was not as efficient in using existing ores as western methods Japan. Rinji Hakurankai Jimukyoku (Chicago Exposition 1893). (1975)). The processes used large amounts of charcoal (which led to deforestation in neighboring areas) and were conducted in small batches in specially constructed furnaces, which would be broken up after several charges. Metallurgy was also quite diverse in practice, since it needed to adjust to the variety of ores found across Japan. For that reason, contemporary reports of production conditions Lyman (1879) and Pumpelly (1866) suggest quite a range of both scale and productivity. Throughout the $1870 \mathrm{~s}$, most — but not all-smaller mines in Japan adhered to traditional methods of both mining and metallurgy. The upsurge in copper exports notable after the early 1870 s reflects primarily the application of western methods to mining (the use of explosives to build mine shafts, conveyance by small trucks on tracks and steam pumps) and to metallurgy. The development of the resource requirements for the A matrix for mineral products used the data on relatively productive sources. One challenge that further research must resolve is providing valuation for the capital invested in mines and metal processing facilities. Copper

Japan possessed a sophisticated and at one time highly productive copper industry. During the period of very limited trade through Nagasaki, Japan exported primarily copper in exchange for goods imported by the Dutch and Chinese. The two largest minds of the early open trade era - the Bekko mine and the Kusakura mine- 
were analyzed by Coignet, et al. (1957) and other observers (see Lyman (1879, pp. 230236)). According to these accounts, significant differences existed in the productivity of these mines, particularly at the gathering and washing stage of the operation (prior to smelting). The data from the Bekko mine found in Coignet, et. al. (1957, p. 81) were used in the A matrix for the copper industry, but other mines would yield much less productivity. ${ }^{44}$ The remaining input requirements were also taken from the Bekko mine, which are found in Coignet, et. al. (1957, p. 130). As is the case with other mines, there is not any reporting of capital for the four stages of processing and the one stage of smelting. Iron

The next most important metals industry in Japan was the iron industry. A nice treatment of the early years of the industry is found in Takeda (1987), who also outlines some of the main steps towards upgrading mining and processing of iron ore. Pig iron and iron manufactures were an important import during the early trade years. Japan's iron industry relied almost entirely upon the smelting of iron from sand iron. Wada (1893,pp. 227-229) describes the Neu iron sand mine and processing operation. At this mine, local farmers gathered iron sands during the off-season. Given a daily wage of about 12 sen, the estimated labor requirement is about 0.5 days per kan (or $3.75 \mathrm{~kg}$.). For the remaining steps of processing, Coignet, et al. (1957, pp. 37, 40-41) provides a useful summary of resource requirements. His data can be checked against the account of Ichiro (1995), which describes some of the variety of production methods for iron, steel and wrought iron. ${ }^{45}$ As with the processing of copper, the resource for which more research is required is the large amounts of wood that was burned either directly or as charcoal, which would often be processed on the spot.

Lead

Japan was a net importer of lead, except during the period 1872-1874. Lead mines shared the fate of other metal mines during the Tokugawa era. Once easily-accessible ores had been worked, the cost of extracting ore (and then processing it) required rising amounts of labor. One lead mine that was visited in the early 1860 s in Hakodate does

\footnotetext{
${ }^{44}$ For example, Lyman (1879, pp. 230-236) reports that from 0.25 to 0.5 person-days per kan were needed to mine and wash the ores at the Kusakura Mine. The requirement was about 0.1 at the (unprofitable) Nameradiki. The Bekko and Kusakura mines supplied much of Japan's copper production during the early trade period. The yield at the Bekko mine was about seven percent of copper ore by weight.

${ }^{45}$ See also Lyman (1879), who visited several iron processing facilities.
} 
provide data on resource requirements. The American mining engineer visited the lead mine at Ichinowatari in Hakodate in 1862 when he was employed by the Bakufu. His report serves as the basis for the estimated resource requirements for lead mining and smelting Pumpelly (1866, p. 81). Unfortunately, Pumpelly's account also lacks any discussion of capital needs, although fuel requirements are well documented.

Tin

Japan imported tin for use in the packaging of tea and other purposes. During the early period of open trade, it had only one tin mine. Fortunately, this mine was also on the itinerary of Lyman's year-long tour of Japanese mines. His report is used for the evaluation of resource requirements in tin Lyman (1879, pp. 169-172). The high labor requirements for both tin and lead reflect the relatively poor quality of the deposits then being worked.

Coal

The final mineral product traded by Japan during the early years of trade was coal. Japan had long had a coal mining industry that served the domestic needs primarily of the salt processing industry. Output was limited because of the circumstances prevailing in other types of mining operations. After the opening up of trade, interest grew in the deposits at Takashima and Miike. Deposits in Hokkaido also attracted attention. One complication in assessing resource requirements for Japanese coal mines is the extensive use of convict labor; some prisons were relocated to be in close proximity to the coal mines Wada (1893, p. 239). As with other mining operations, the resource requirements for coal mining varied widely among mines depending upon the thickness of the seam and its proximity to the surface. For assessing the resource requirements for coal, data from the late 1860s in Hokkaido were used Kasuga (1982). As is the case with other mineral industries, there was no information on the size of the capital investment in this mine (the Kayanuma Coal mine). 